OECD Economics Department Working Papers No. 120

OECD's Indicators

of International Trade and Competitiveness

\section{Martine Durand,}

Jacques Simon,

Colin Webb 
GENERAL DISTRIBUTION

OCDE/GD ( 92$) 138$

ECONOMICS DEPARTMENT

WORRING PAPERS

NO. 120

OECD'S INDICATORS OF INTERNATIONAL TRADE AND COMPETITIVENESS

by

Martine Durand; Jacques Simon and Colin Webb Foreign Trade and Investment Divișion

ORGANISATTION FOR ECONOMIC CO-OPERATION AND DEVELOPMENT

Paris 1992

44854

ONLY THE REFERENCE OF THIS DOCUMENT IS AVAILABLE ON OLIS 


\section{OECD'S INDICATORS OF INTERNATIONAL TRADE AND COMPETITIVENESS}

This paper presents the methodology adopted by the Economics Department to calculate indices of effective exchange rates and indicators of competitiveness, based on unit labour costs and export unit values in the manufacturing sector. The calculation derives from a double-weighting system which first measures competition among alf competitors of a given country on each of its markets, this competition being then weighted according to the relative importance of each of the markets of the country in question. These indicators are generally used to analyse trends in trade variables. In this paper, indicators of export market growth and export performance are also calculated and compared with the export competitiveness indicators.

Cet article expose la méthodologie générale adoptée par le Département des Affaires Économiques pour calculer des indicateurs de compétitivité, basés sur des couts unitaires de main-d'oeuvre et des prix à l'exportation dans le secteur manufacturier, ainsi que des indices de taux de change effectif. Le calcul de ces indicateurs est fondé sur un système de double pondération mesurant d'abord la concurrence que se livrent tous les concurrents d'un pays donné sur chacun des marchés considérés, cette concurrence étant ensuite pondérée selon l'importance relative de chacun des marchés de ce pays. Ces indicateurs sont généralement utilisés pour analyser les évolutions du cơmmerce pertérieur. Dans cet article, des indicateurs de croissance de marchés et de performance à l'exportation sont également calculés et leur évolution est comparée à celle des indicateurs de compétitivité à l'exportation. 
Table of Contents

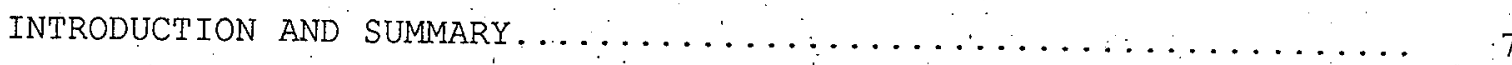

I. PRICE AND COST COMPETITIVENESS $\ldots \ldots \ldots \ldots \ldots \ldots \ldots \ldots \ldots \ldots$

A. The definition of competitiveness $\ldots \ldots \ldots \ldots \ldots \ldots \ldots$

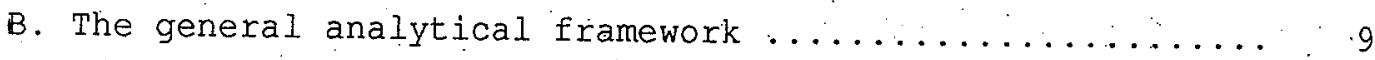

II. THE MEASURES OF COMPETITIVENESS CALCULATED BY THE OECD ..... 9

A. Import competitiveness $\ldots \ldots \ldots \ldots \ldots \ldots \ldots \ldots \ldots \ldots \ldots \ldots \ldots \ldots \ldots$

B. Export competitiveness ..................... 10

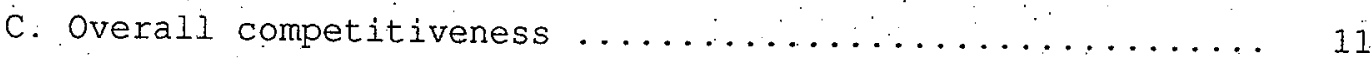

D. Export competitiveness in the INTERLINK model $\ldots \ldots \ldots 12$

E. Comparison of the indicators of competitiveness constructed by the OECD and other organisations ....... 13

III. . COMPETITIVENESS AND TRADE PERFORMANCE $\ldots \ldots \ldots \ldots \ldots \ldots \ldots \ldots$

A. Trends in OECD's competitiveness indicators $\ldots \ldots \ldots \ldots \ldots 14$

B. Indicators of export performance ............. 23

C. Export competitiveness and export performance ....... 24

Tables

Graphs

NOTES

BIBLIOGRAP HY

Annex 1

Annex 2

Annex 3

Annex 4 


\title{
OECD'S INDICATORS OF TRADE AND INTERNATIONAL COMPETITIVENESS
}

\author{
Martine Durand, Jacques Simon and Colin Webb (1)
}

\section{INTRODUCTION AND SUMMARY}

$\because$ The concept of competitiveness encompasses many factors that impact on a country's macroeconomic performance. They include productivity and technological innovation, which in turn depend on investment in human and physical capital, and on the institutional and structural policy environment. Competitiveness is particularly important for a country's performance in the tradeable sector which is the focus of this note. This sector has become increasingly important in industrialised countries and has a large influence on their overall performance.

Measures of international competitiveness have been developed by the Secretariat primarily as a tool to analyse and forecast international trade trends... In principle, all factors influencing a country's trade performance should be included in the calculation of such measures. But some of the relevant factors are qualitative, or do not lend themselves readily to. quantification, such as the quality of the products involved, or the value of after-sales service. Hence, for practical reasons the analysis here is confined to relative competitive positions that are easier to quantify: those related to international cost or price differentials or, more precisely, to changes in such relative measures.

Even with this restriction, a large number of methodological problems are involved in constructing such indicators of competitiveness. These issues are addressed in this note. In particular, it is shown that the construction of indicators hinges on what aspect of competition is under study. Thus, various measures of import, export, or overall competitiveness are identified, together with their respective fields of application. Furthermore, for one and the same definition, a number of different measures of competitiveness may be advanced, deperiding on the components used to construct them, the geographical coverage and the level of aggregation of markets and competitors. Part $I$ of the paper discusses the various aspects of price and cost competitiveness and describes the general analytical framework of the different indicators. In Part II, the technical aspects entering the construction of these indicators are reviewed in detail. Finally, Part III presents trends in the Secretariat's measures over the longer run and provides an analysis of their relationship to measured trade performance. It is suggested there that, despite the serious problems posed by construction and aggregation, indicators of competitiveness are a useful analytical and forecasting tool, and measures calculated by the Secretariat shed light on trends and prospects in trade volumes of imports and exports of manufactured goods. 


\section{PRICE AND COST COMPETITIVENESS}

\section{A. The definition of competitiveness}

In constructing competitiveness indicators it is important to recognise that any particular indicator may be relevant for only one aspect of trade
performance. Ultimately, the role of price competitiveness indicators is to act as a yardstick of price competition between producers located in different clearly the particular thus necessary, in constructing indicators, to specify define both the count aspect of competition that is being investigated, and to and the markets and prodict relative to which competitiveness is to be measured

Thus the measurement of a country's competitiveness will be a both by the location and the structure of the markets fill be affected calculated. Several possible approaches may be adopted for which it is purpose to which the proposed indicator is to three options: study may be confined to each be put. In practice, there are home market, or both. Vory markets, to its measurement of competitiveness depending ial differences can arise in the measent of competitiveness depending on the markets chosen for analysis.

Once the markets have been decided upon, it is necessary to select the countries relative to: which it is wished to measure competition. In the limit, all actual and potential competitors in the world should be considered: can be taken into account generally imply that only a sub-set of competitors of developing countries whose trade the OECD countries and a small number Furthermore, some analysts mase trade is significant on a world scale. own country relative to its main competitors on in the performance of their

Finally, to obtain a comprehensive picture of competition by exporters and producers on given markets, it would in principle be necessary to carry out detailed a breakdown categories of tradeable goods and services, with as confined to aggregate measures of In practice, such studies are normally difficulties in extending the analysis macturing output, because there are particular, many iservices are tradedis to other groups of products. In often unreliable. As for transactions in stistics on service prices are materials, they often take place. markets where price differentiace on world markets or on highly regulated of regulatory frameworks than of price often more indicative of the importance

The measurement of international competitiveness is-- even within a well-defined conceptual framework -- very much a matter of choices and compromises with available data, and it entails a number of tradeoffs among different criteria and objectives. The secretariat calculates indicators of relative competitiveness based on the export unit values of manufactures, unit labour costs in manufacturing and consumer price indices (3) that are published twice yearly in the Economic Outlook. For purposes of international generally the U.S. dollar. cost) differential is then The competitiveness represented by a price (or nominal effective exchange rate, an indicat effective exchange rate (4). The literature, is only one factor an indicator that is often mentioned in the ( 
relative price (or cost) being the other one. For internal use in connection with the running of the Secretariat's INTERLINK model, somewhat different competitiveness measures are also computed." While these measures all differ from each other in detail they all stem from a common analytical framework, which is briefly described below.

\section{B. The general analytical framework}

The indicators of competitiveness calculated by the secretariat's form part of a more general analytic framework based on the Armington approach (1969a). This is defined by a particular characterisation of the measures of price competition and of the way in which these measures affect foreign trade variables (export and import volumes and trade balances). The measures of competitiveness are explicitly defined price (or cost) differentials based on weighted averages whose weighting pattern varies according to the notion of competitiveness and the particular aspect of trade performance under study. It is the choice of these weights that are a significant feature of the construction of the Secretariat's indicators because competitiveness indicators in this framework are defined such that the resulting measures all exhibit global consistency. Overall, gains and losses of competitiveness for the set of countries analysed should add up to zero and the secretariat measures respect this property (at least in principle, though data problems generally result in small inconsistencies in practice).

In the INTERLINK model, the indicators of import and export competitiveness - are in principle global in their coverage, including the entirety of world trade in manufactures: they measure competition among the twenty-three OECD countries and the six non-OECD country groupings (5) on the markets made up by these countries of country groupings.. The indicators published in the Economic outlook are somewhat more restricted in country coverage, involving only those competitors and markets where data of adequate quality are available: At present, these indicators provide a composite measure of import and export competitiveness covering nineteen OECD countries and four of the Dynamic Asian Economies (DAEs) (6). The analytic method underlying both these sets of indicators is set out below.

\section{THE MEASURES OF COMPETITIVENESS CALCULATED BY THE OEĊD}

\section{A. Import competitiveness}

Import competitiveness is measured by the differential between the producers' market price and that of their competitors, the latter being defined as :

$$
\mathrm{PCM}_{\mathrm{k}}=\Sigma \mathrm{m}_{\mathrm{ik}} \cdot \mathrm{PX}_{\mathrm{ik}}
$$

where $\mathrm{PCM}_{\mathrm{K}}$ is the competitors' price on market. $k$ (7)

$P X_{i k}$ is the country $i^{\prime} s$ export price to country $k$

and $m_{i k}$ is competitor $i^{\prime} s$ market share in $k^{\prime} s$ total imports. 
This weighted average of bilateral export prices PCM is in fact an approximation of the import price $\mathrm{PM}_{\mathrm{k}}$ on market $k$. $\mathrm{PCM}_{\mathrm{k}}$ and $\mathrm{PM}_{\mathrm{k}}$ differ in practice for two reasons: first, there are statistical divergences between the price measures supplied by the exporting and importing countries second, are only imperfect substitutes markets which are used as proxies for the PXiks discrimination by exporters on differilateral export prices because of price the past is expressed by:

$$
P_{k}-P M_{k}
$$

where $P_{k}$ is the producer price on market $k$ and $\mathrm{PM}_{k}$ denotes the actually measured, rather than the constructed, deflator of imports on market $k$. In forecasting, $\mathrm{PCM}_{\mathrm{k}}$ is used as a proxy for $\mathrm{PM}_{\mathrm{k}}$

This measure of import competitiveness is used in the equations of import volumes of manufactures in the INTERLINK model. However, given the lack of homogeneity across countries in the producer price series, the model uses domestic demand deflators instead of producer, prices as the measure of domestic
prices in each market (8).

\section{B. Export competitiveness}

While the measure of import competitiveness is obtained by a relatively straightforward procedure, the measure of export competitiveness is somewhat more complex. Competitiveness of a given country's manufactured export volumes is the differential between the country's export price and that of its competitors on their common markets. On the assumption that a country's export prices do not depend on the country of destination (9); competitors export prices are calculated by a double weighted method.

Broadly speaking, the underlying rationale is the following take, for example, the'U.S. market, where an exporting country is competing not only with (weighted). producers but also with other countries exporting to that market. The determined by the of a given country's competitors on the U.S. market is price of the country's of supply (output plus imports) on that market. The aggregating its competitorsetitors on all of its markets is. then obtained by its exports:

Thus, on market $k$, the weighted average price of country "i"'s competitors will be given by the average of the local producers prices and
export prices of countries exporting to $k$ :

$P C X_{i k}=\left[\frac{S_{k k}}{1-S_{i k}}\right] \cdot P_{k}+\underset{j \neq i, k}{\sum}\left[\frac{S_{j k}}{1-S_{i k}}\right] \cdot P_{j}$

where PCX ik is the price of i's competitors on market $k$

$\mathrm{P}_{\mathrm{k}} \quad$ is the producer price on market $k$

$\mathrm{PX}_{j} \quad$ is the export price of country $j$ 


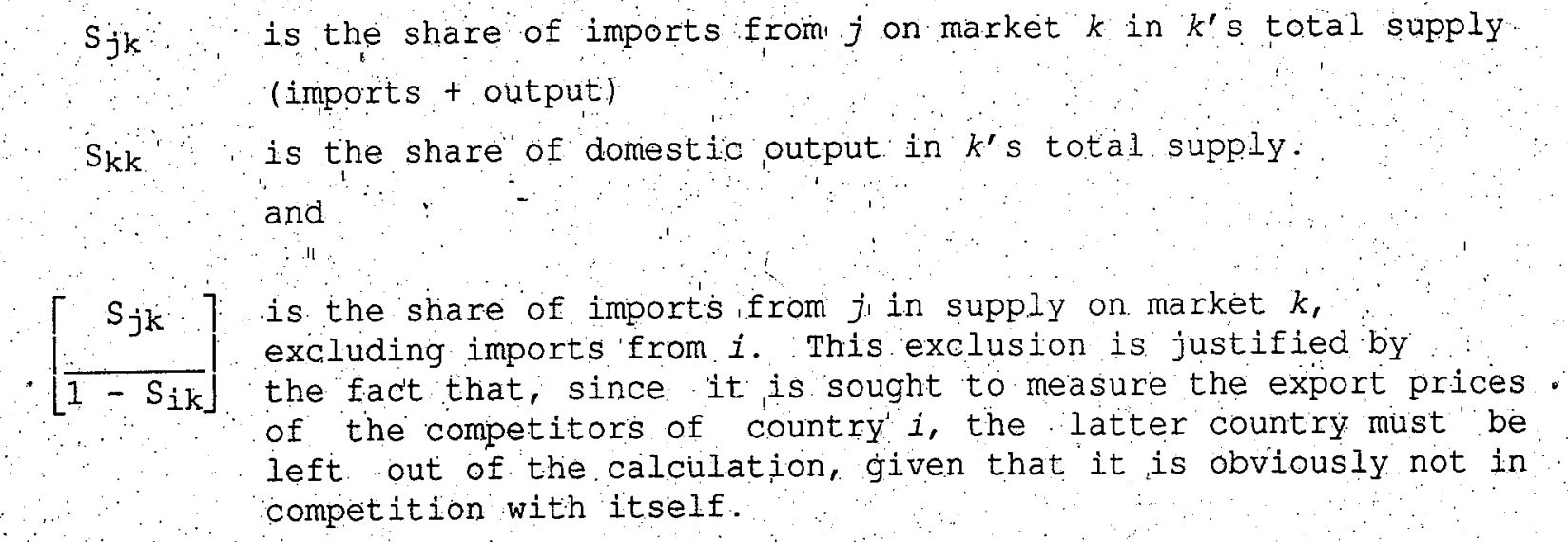

The price of country i's competitors on all markets is then calculated by aggregating the prices of competitors on each market according to the export pattern of country i... Thus:

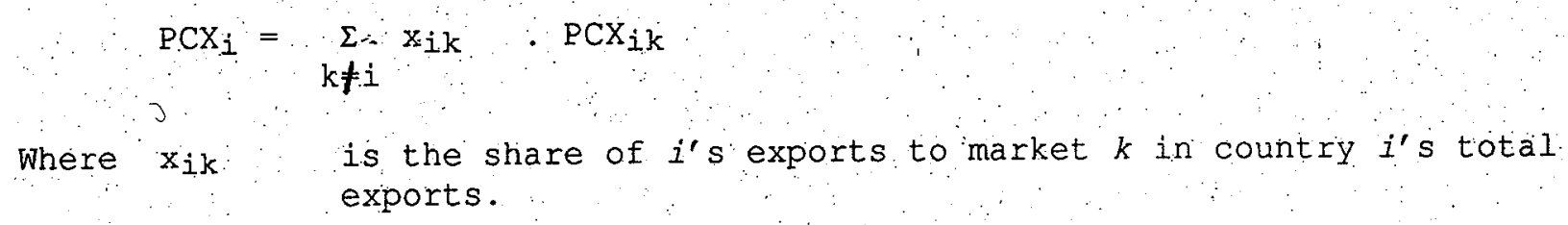

It is, finally, the term $P X_{i}-P C_{i}$ that ultimately expresses the export competitiveness of country $i$.

The same type of calculation may be made using variables for unit labour costs, and a comparison of cost and price competitiveness indicators can serve as a rough indicator of changes in relative profit margins of exporters. These calculations can also be made with indices of exchange rates to derive nominal effective exchange rates.

\section{c. Overall competitiveness}

The Secretariat also calculates indicators of overall competitiveness which provide an average measure of countries' competitive position on their home markets as well as on their export markets. In this case, the price of country i's competitors on a given market $k$ is defined, as above, according to the pattern of total supply on this market (imports + domestic output) (10) (with the same notation as in (B.)):

$$
\operatorname{PCX}_{i k}=\left[\frac{s_{k k}}{1-s_{i k}}\right] \cdots P_{k}+\sum_{j \neq k, i}\left[\frac{s_{j k}}{1-s_{i k}}\right] \cdot \operatorname{PX}_{j}(k \neq i)
$$

and $\operatorname{PCX}_{i i}=\sum_{j \neq i}^{\sum} \frac{S_{j i}}{1-S_{i i}} \cdot \operatorname{PX}_{j}$

Here, too, the price of country i's competitors in all markets is defined by aggregating its competitor's prices on all its markets, including 
the "home market, according to the pattern of demand directed at country $i$ (exports + domestic demand):

$$
\mathrm{PCX}_{i}=\sum t_{i k} \mathrm{PCX}_{i k}
$$

where $t_{i k}=$ share of demand directed at $i$ by country $k$ in total demand directed at $i$

and hence

$t_{i i}=$ share of domestic demand in total demand directed at $i$

It can be shown that, in this case, competitiveness is indeed a proxy of a weighted average of export and import competitiveness, with weights equal to $\left(1-t_{i i}\right)$ and $t_{i i}\left(1-s_{i i}\right)$ respectively. Here again, the same calculations can be made using exchange rates and unit labour cost variables. Relative profitability derived by comparing overall cóst and price competitiveness relates, in that case, to both domestic producers and exporters.

This approach thus gives a measure of overall competitiveness, since it is based on the concepts of total demand directed at countries and total supply on the markets. In particular, a country's competitiveness takes into account demand on the home market. Furthermore, on all markets in which the country is present, the influence of domestic producers is taken into account. These calculations however, require a specification of what proportion of .. domestic goods' should be considered to be competing with imported goods. The point here is that it may not be realistic to consider all of domestic production as being in competition with imports. The indicators of overall competitiveness calculated by Secretariat do not incorporate this refinement: all of domestic production is implicitly assumed to compete with imports on all markets.

\section{Export competitiveness in the INTERLINK model.}

In INTERLINK, two factors effectively go to explain changes in exports: growth of export markets (see Part III) and changes in countries' price competitiveness. This specification of the. INTERIINK equations leads to a definition of indicators of export competitiveness that can be illustrated by a two-stage schema (although, in practice, the steps will occur simultaneously and not recursively). First, it is assumed that, on each market, there is an. initial supply split between domestic and foreign producers, depending on the relative import competitiveness of the domestic producers: This determines the total demand for imports. In the second stage, the distribution of imports among competing foreign suppliers is determined by relative export competitiveness. Competition at this. stage is only among exporters themselves. Seeing the process in this way, leads to a strict notion of export competitiveness (11), às compared with the notion of export competitiveness defined above.

Thus; in INTERLINK, manufactured export volume equations which are used by the Secretariat in its forecasting process include a competitiveness term where the price of a given country's competitors on each market is determined solely by the pattern of imports on that market, i.e. (with the same notation as in (A)): 


$$
\operatorname{PCX}_{i k}=\sum_{j \neq i, k}^{\Sigma} \frac{m_{j k}}{1-m_{i k}} \operatorname{PX}_{j}
$$

competitors' prices on all the markets still being determined in the same way according to the export pattern of the country in question, i.e.:

$$
\mathrm{PCX}_{\mathrm{i}}=\sum_{\mathrm{k} \neq \mathrm{i}} \mathrm{X}_{\mathrm{ik}} \mathrm{PCX}_{\mathrm{ik}}
$$

Competitiveness thus defined by $P X_{i}+P_{1}$ gives a measure of export competitiveness strictly defined.' It should, however, be noted that this measure does not determine the overall impact of price changes on export performance in the INTERLINK model. This is because each countries' export prices influence competitiveness both directly and indirectly: directly by affecting a countries' capacity to compete with other exporters on a given market; and indirectly by influencing the relationship between domestic and foreign prices on each market, and so affecting the (predetermined) rate of overali market growth. It would be possible to simulate with the INTERLINK model a country's export price changes, and then observe the overall impact on the country's export volumes as well as on those of its trading partners. This procedure would generate a weighting system reflecting competitiveness effects for all countries, together with non-competitiveness, factors such as substitution effects between products. This method of simulating a global trade model with price changes lies behind the MERM weights of the IMF (12): The IMF weights, however, are derived from simulations that look at changes in manufactures trade balances in value terms and hence take into account effects other than just export competitiveness.

\section{E. Comparison of the indicators of competitiveness constructed by the OECD and other organisations}

To the extent that various technical factors discussed in the preceding section . enter into the indicators of competitiveness constructed by different organisations in different ways, divergences are likely to arise in the measures produced. In practice, there are two principal sources for divergence: the number of countries used in the calculations, and the weighting pattern adopted.

As regards the weighting pattern used in constructing measures of competitiveness:

-- Many organisations use bilateral or multilateral export weighting patterns. These systems are in fact special cases of the Secretariat's double weighting system for export competitiveness described in II B above. If it is assumed, first, that on each market, a country's only competitors are domestic producers in that market and, second, that competitiveness between countries is determined only on their own markets, then the double weighting pattern collapses to a single. weighting pattern based on bilateral exports. Such a system does not take account of competition between two countries on third markets. Alternatively, if it is assumed that there is only one market, namely the world market, and that on this 
market competition operates between exporters (excluding domestic producers), the double weighting pattern is simplified to a single multilateral weighting pattern 'involving only the relative weights of each country's exports in world trade.

- Similarly, weighting patterns for overall trade competitiveness based on bilateral imports and exports are special cases of the double weighting pattern used by the secretariat. These patterns consist in calculating import competitiveness and export competitiveness separately, and then combining these measures either with equal weight, or with weights reflecting the ratio of imports to exports.

- Finally, indicators calculated on the basis of a MERM-type weighting are obtained by "shocking". a model and observing the results on a specific variable (imports, exports or trade balance) for a country and its trading partners.

Measures of competitiveness depend a great deal on what aspect of price competition it is wished to study. However, once that has been determined, some indicators will provide more accurate measures than others. In Table 1, an attempt is made to sumarise the fields of application of the main types of competitiveness that may be measured, together with the underlying assumptions. Table 2 pin-points the main differences in approach for indicators calculated by the secretariat and other organisations.

\section{COMPETITIVENESS AND TRADE PERFORMANCE}

\section{A. Trends in $\mathrm{OECD}^{\prime} \mathrm{s}$ competitiveness indicators}

Chart A shows trends since 1975 for 19 OECD countries and 4 of the Dynamic Asian Economies in the indicators for import, export and overall competitiveness described in Part II.' Two measures of overall competitiveness are given here - that of relative export prices and that of relative unit labour costs - in order to take into account trends in relative profitability
in manufacturing.

The overall competitive positions of the three major OECD countries are strongly influenced by movements in the dollar exchange rate. Thus, the depreciation of the U.S. dollar between 1976 and 1978, and again from 1986 to 1988, corresponds to periods of loss of relative competitiveness for Japan and Germany. Similarly, the rise in the U.S. relative unit labour costs (or put another way, the appreciation of the real effective exchange ratel from 1981 to 1985 led to an improvement in the competitive positions of these countries. A remarkable feature in the case of Japan is the marked difference in the amp'litude of variations in relative unit labour costs and relative export prices. This suggests that, by and large, Japanese exporters pursue a policy of squeezing (increasing) their margins whenever their competitiveness is declining (improving)-(13), while in the U.S., exporters generally set their prices with primary regard to production costs even when the dollar is appreciating (as was the case in the period between 1981 and 1985).

In EMS countries other than Germany, patterns of relative competitiveness do not show a uniform trend. France, Belgium and the 


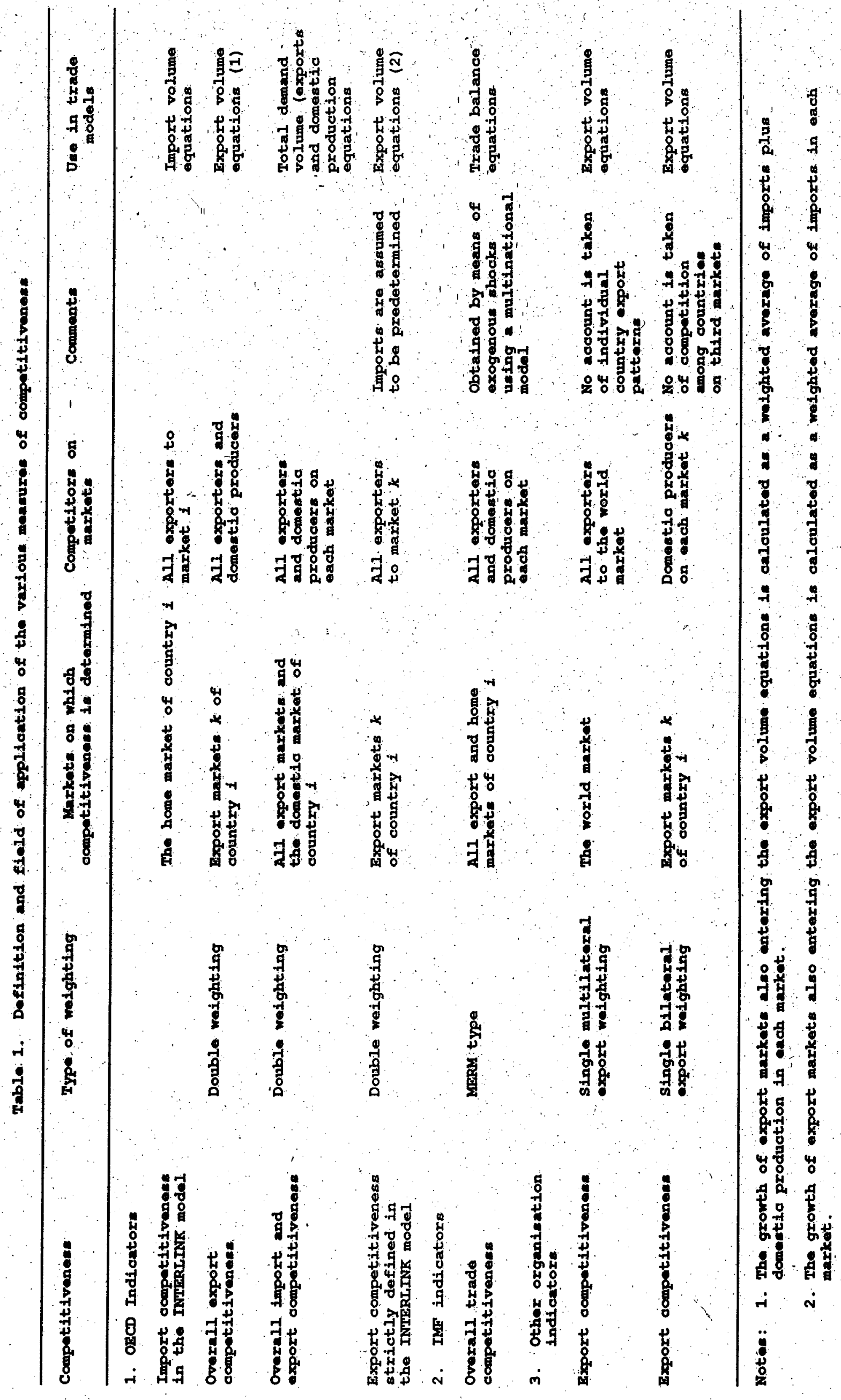




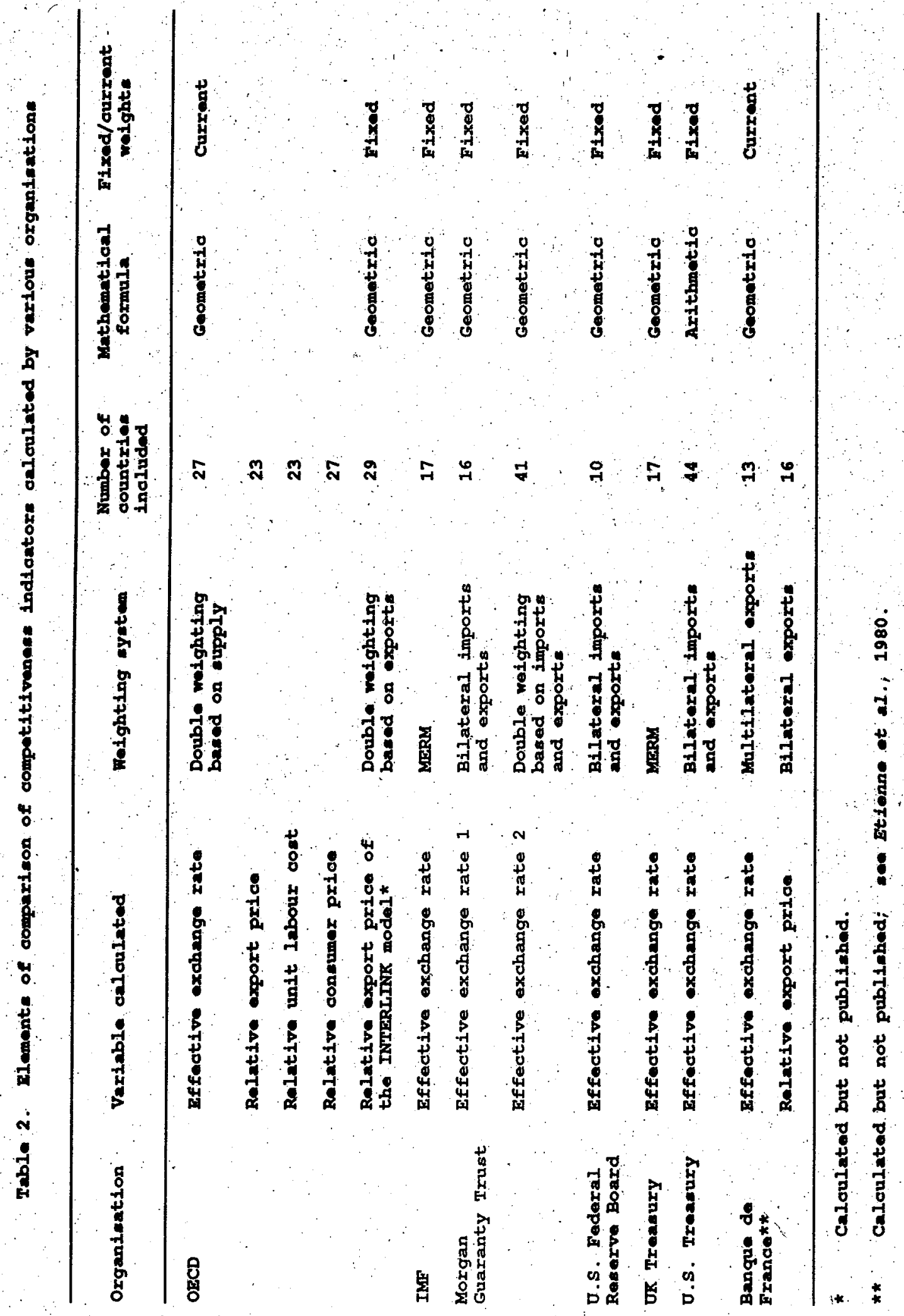




\section{Chart A. TRENDS IN THE OECD'S INDICATORS OF COMPETITIVENESS}

(Note: a rise in the index denotes a loss competitiveness)

Overall competitiveness

relative unit labour costs

relative export prices
Import and export competitiveness

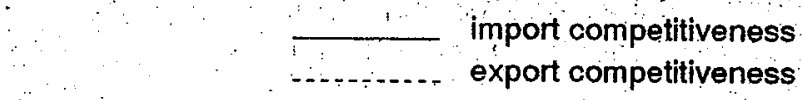

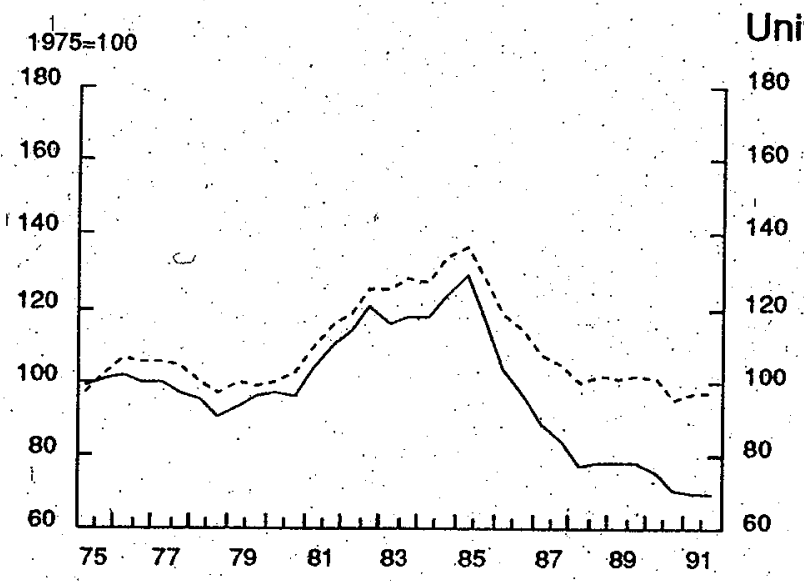

United States

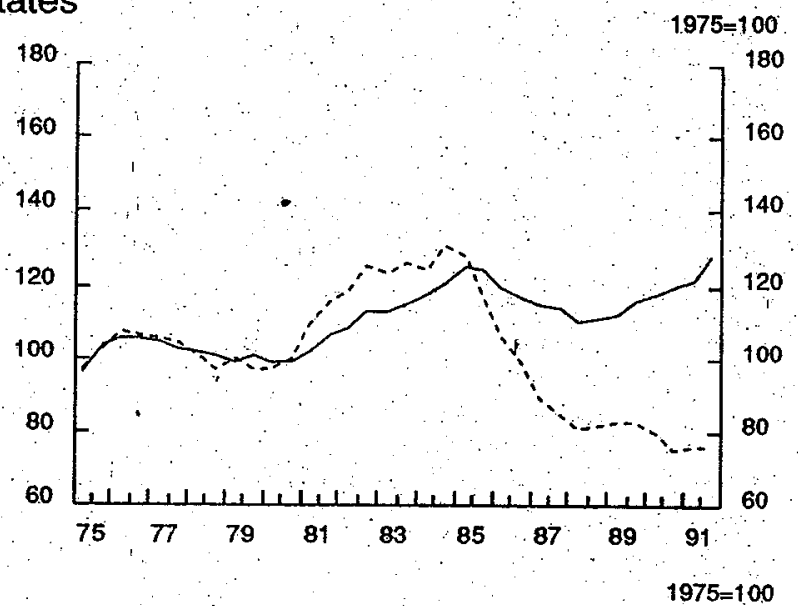

$1975=100$

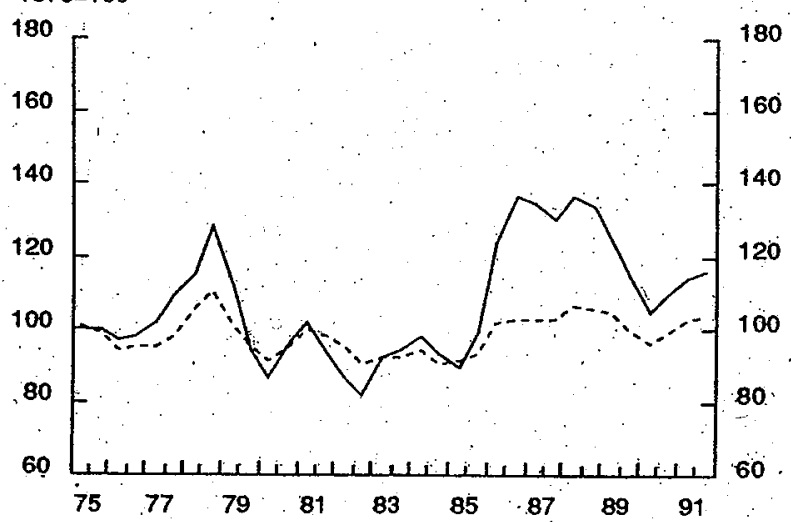

Japan

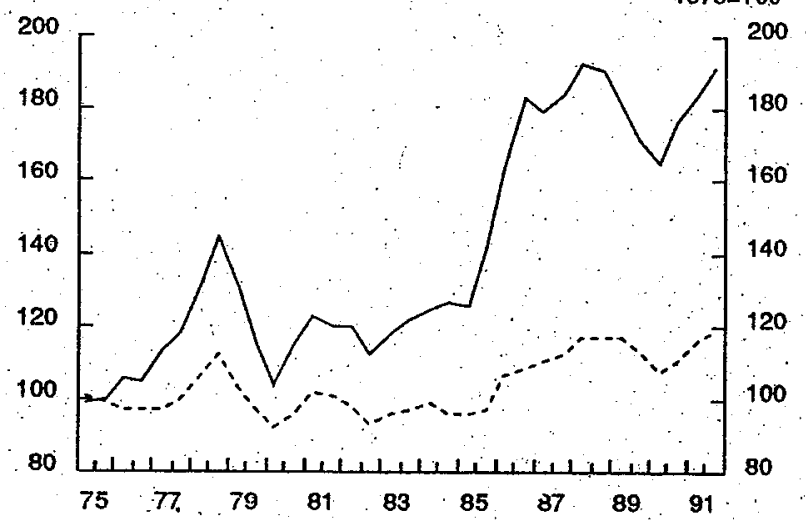

Germany
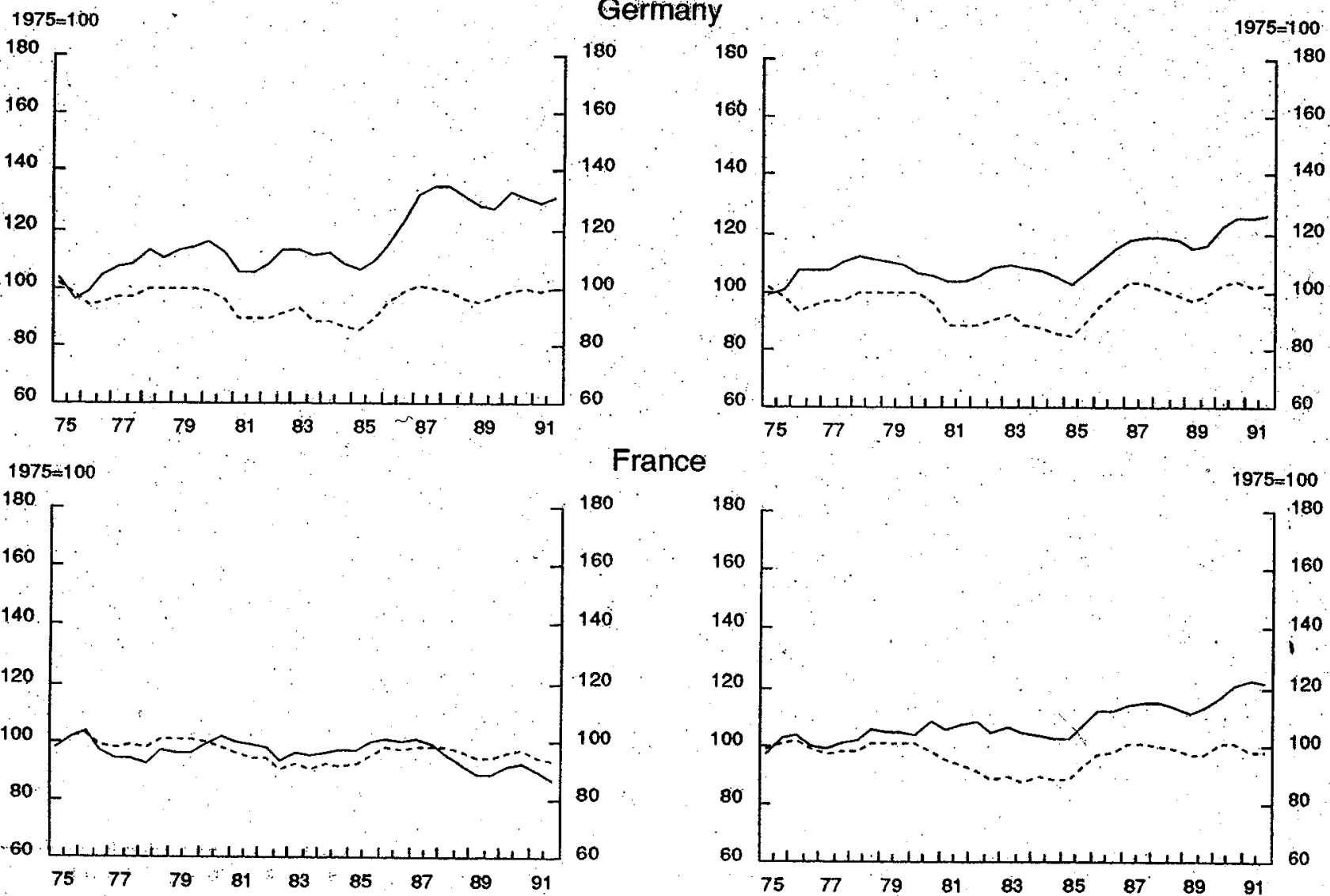

France

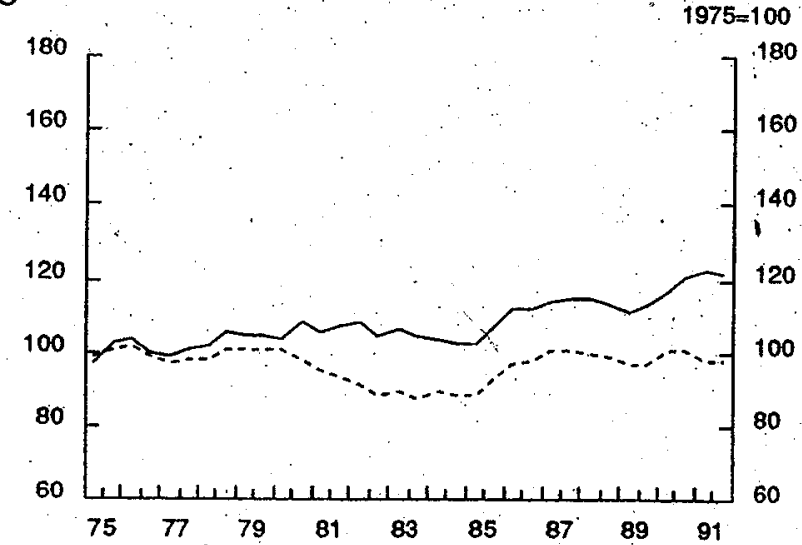




\section{Chart A (cont'd).}

\section{Overall competitiveness}

relative unit labour costs

relative export prices :

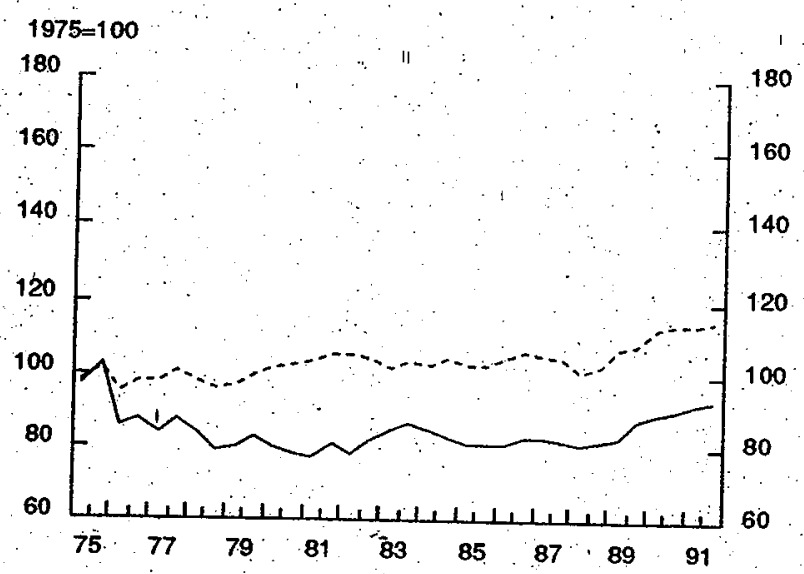

\section{Import and export competitiveness}

Italy

mport competitiveness

export competitiveness
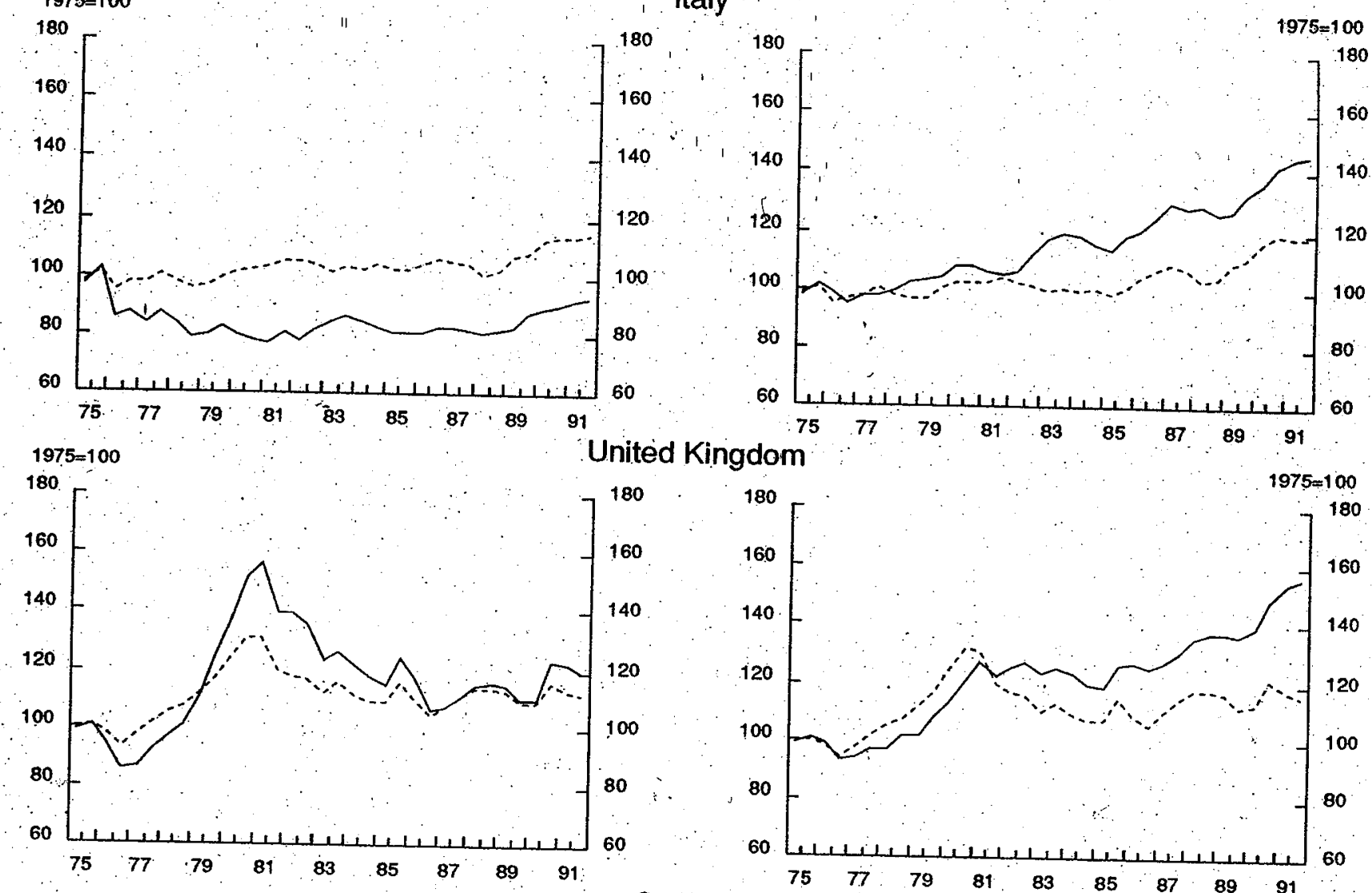

United Kingdom

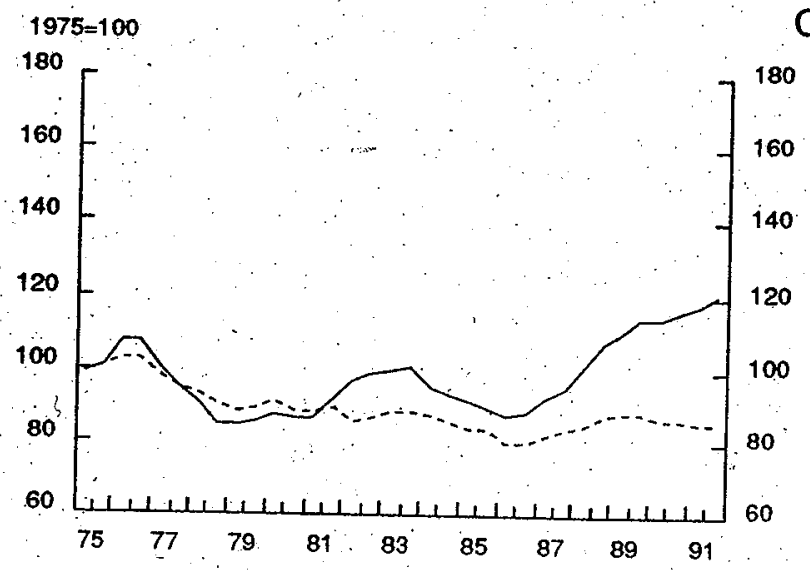

Canada
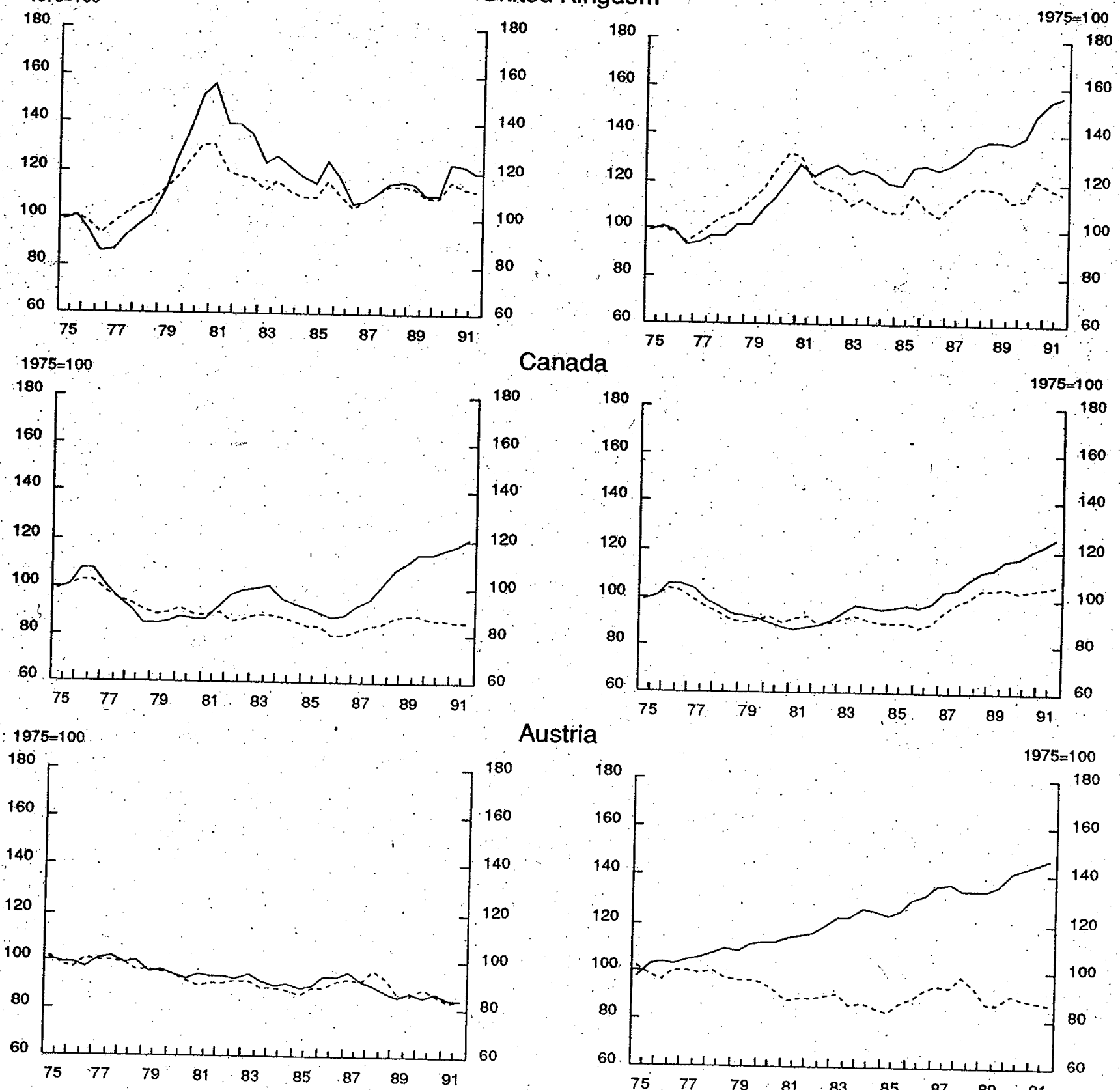

Austria

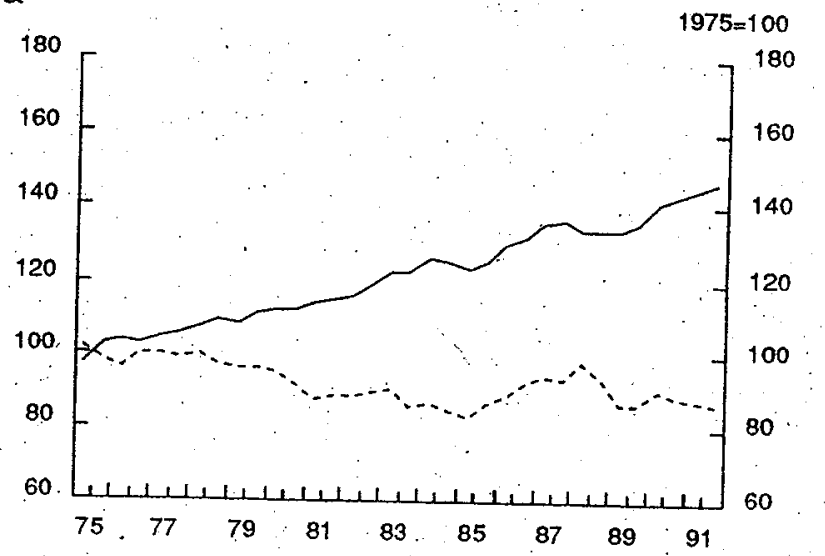


Chart A (cont'd).

Overall competitiveness

relative unit labour costs

relative export prices
Import and export competitiveness

import competitiveness

export competitiveness

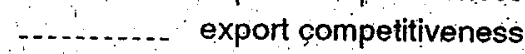

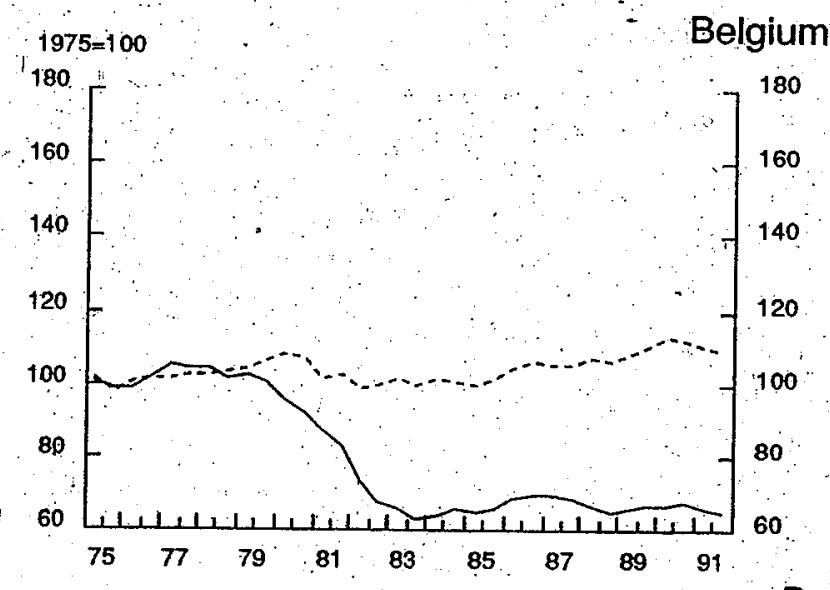

uxemburg

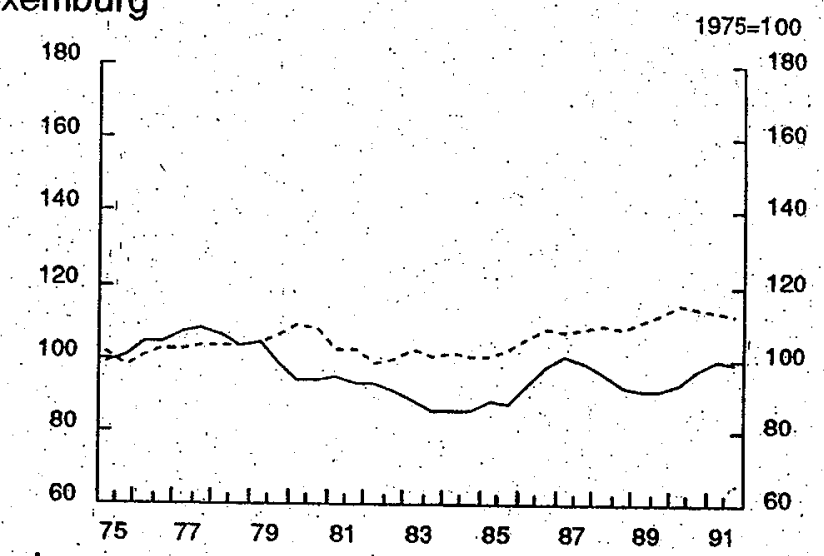

$1975=100$

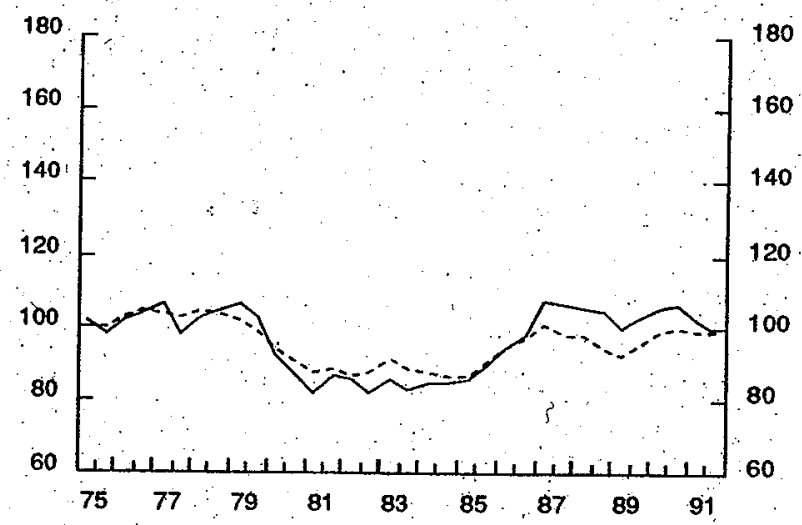

Denmark

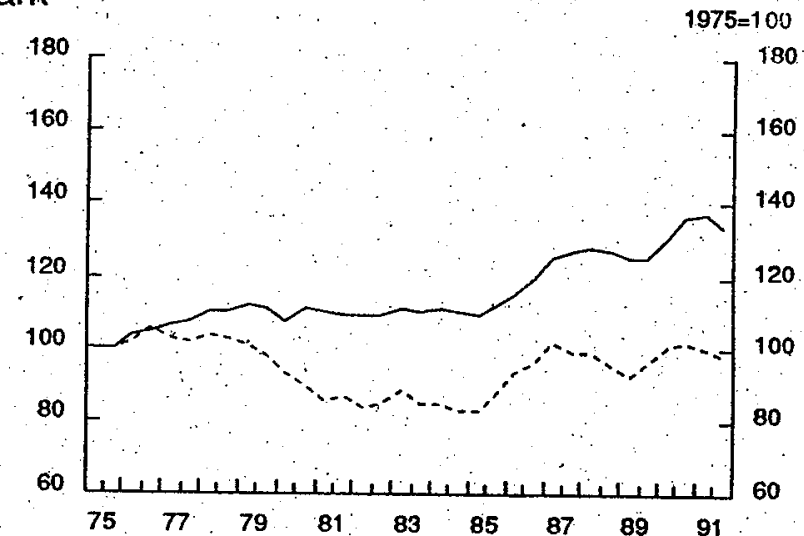

Finland
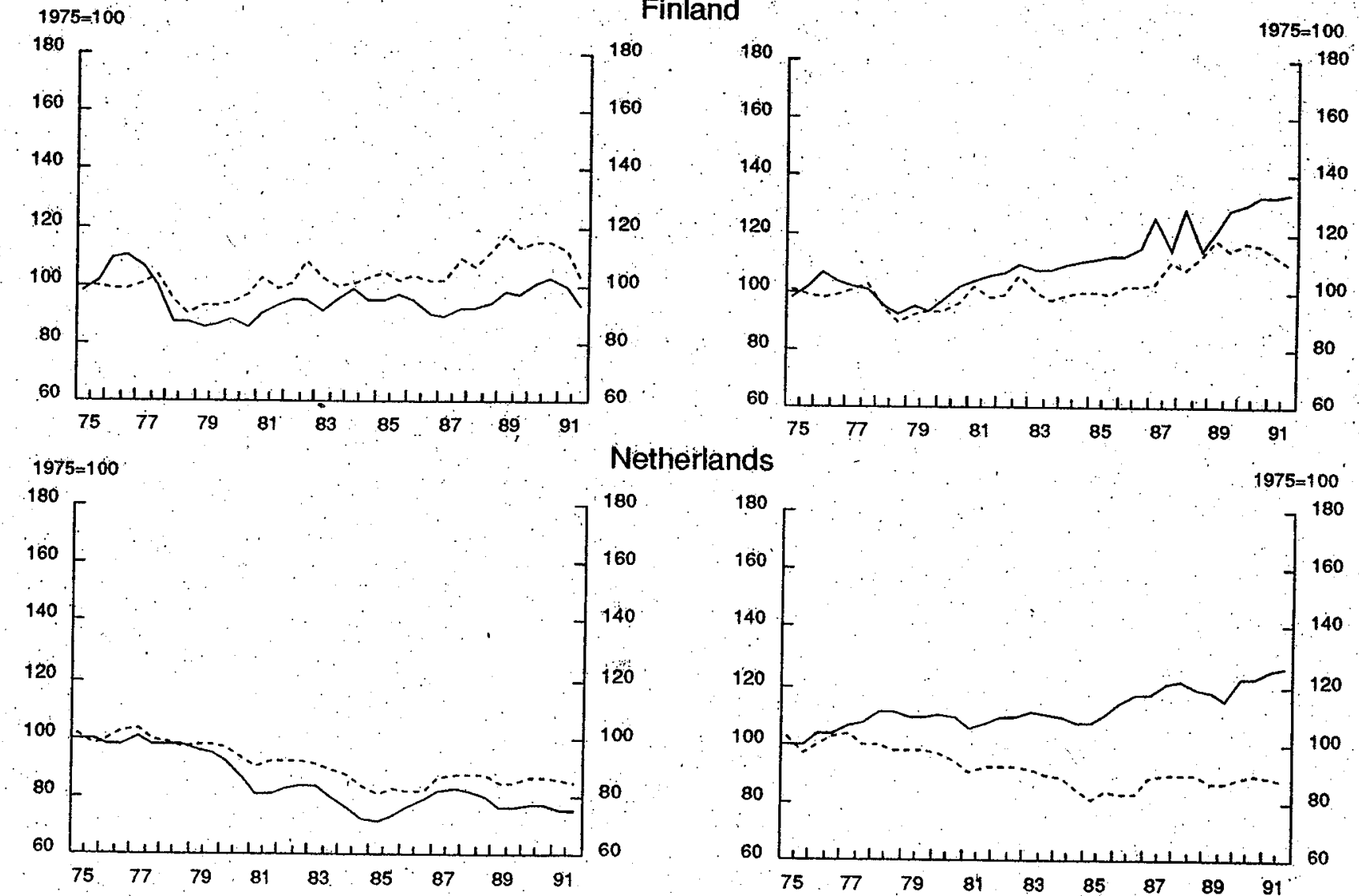

Netherlands

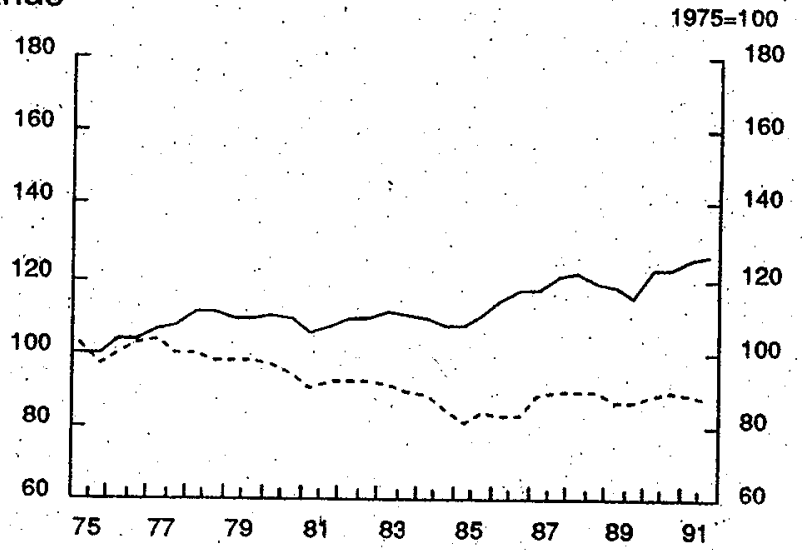




\section{Chart A (cont'd).}

\section{Overall competitiveness}

relative unit labour costs relative export prices
Import and export competitiveness

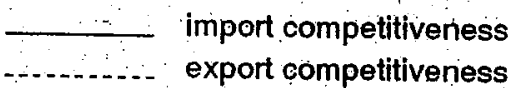

Nonway
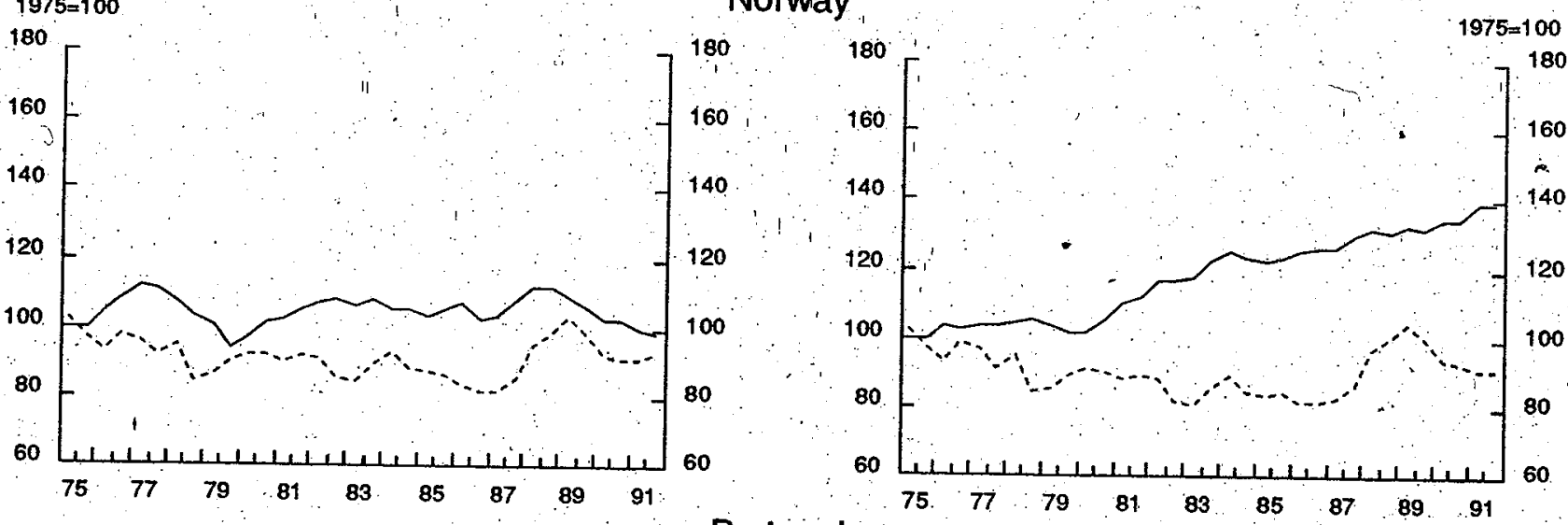

Portugal
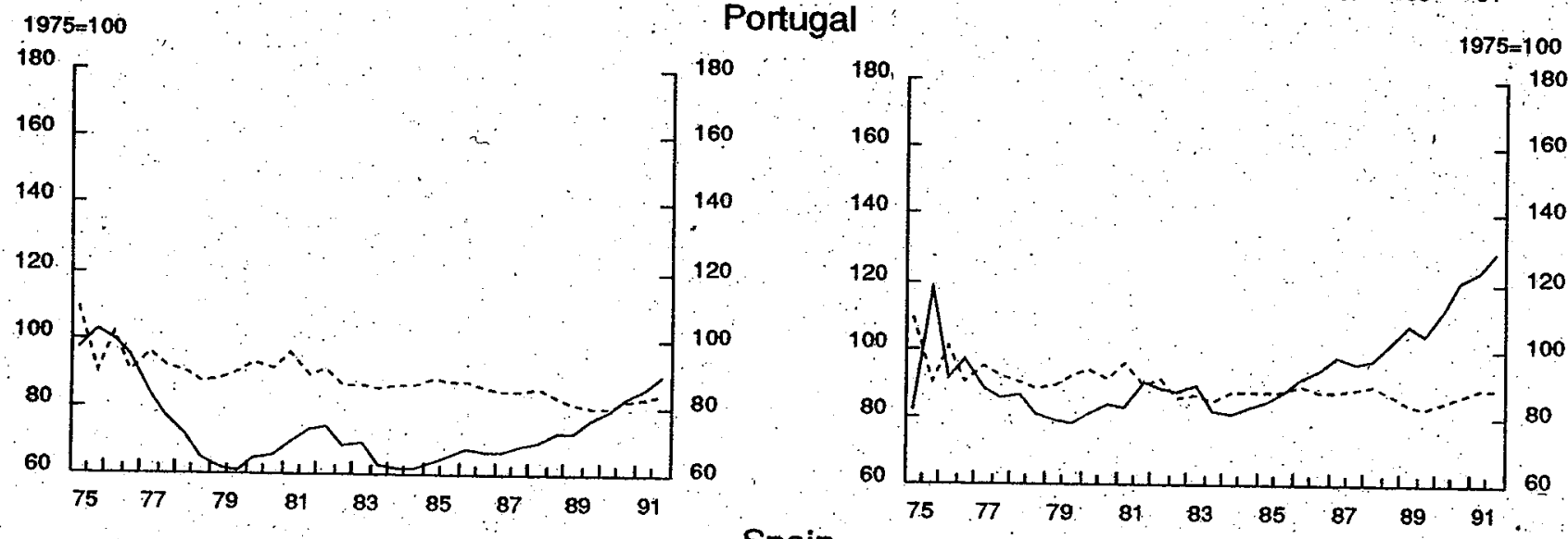

$1975=100$

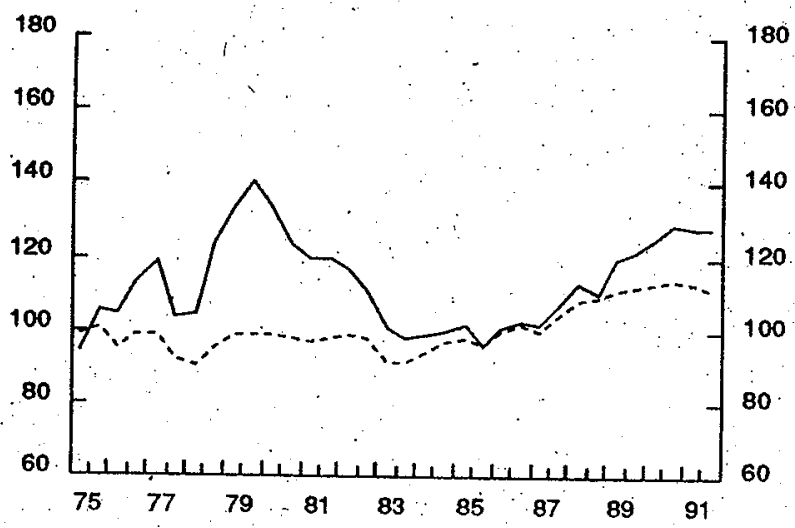

Spain

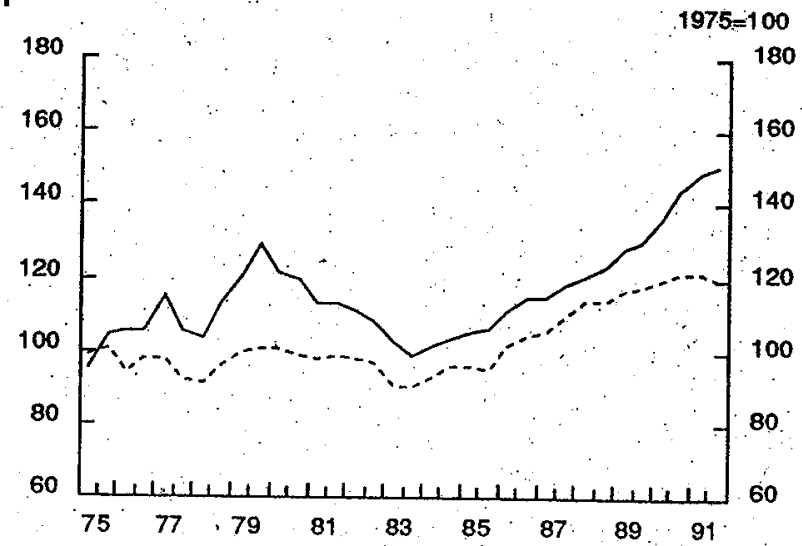

Sweden
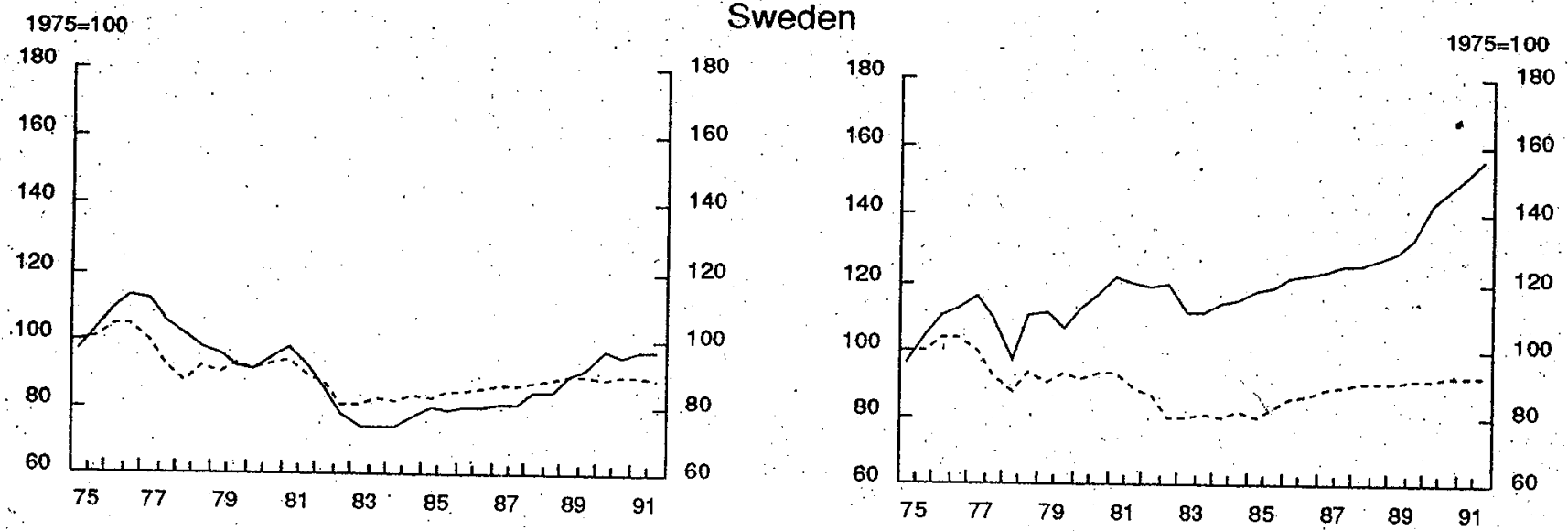


\section{Chart A (cont'd).}

Overall competitiveness

relative unit labour costs

relative export prices

\section{Import and export competitiveness}

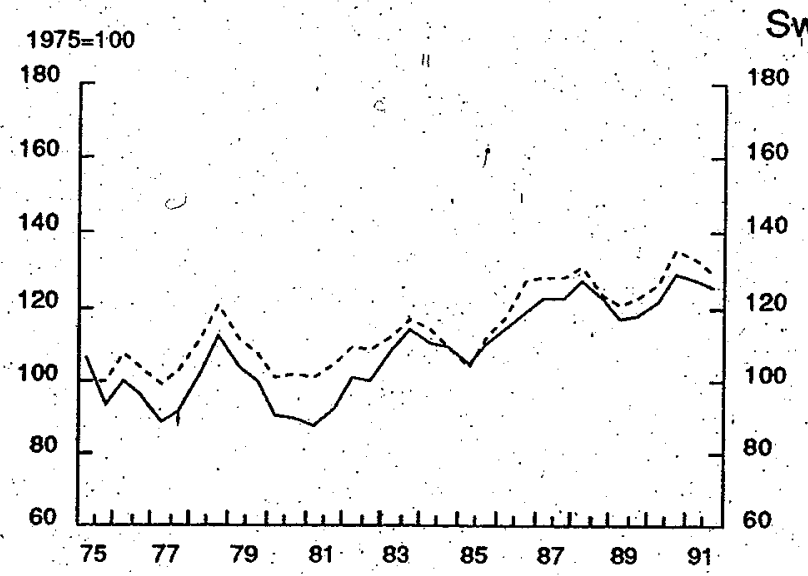

Switzerland

import competitiveness

export competitiveness

1975=100

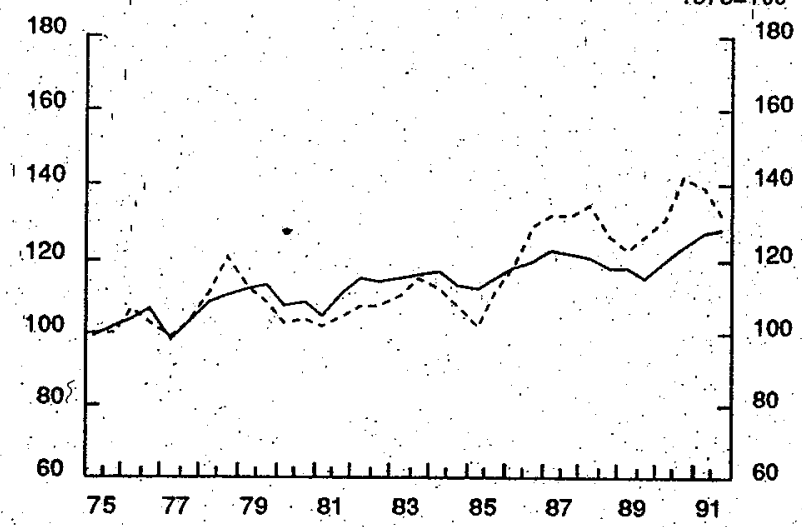

$1975=10,0$

Australia

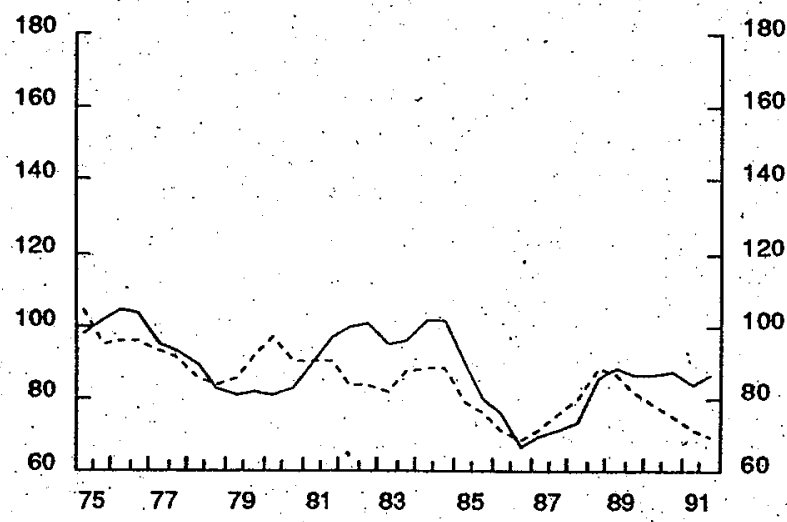

Australla
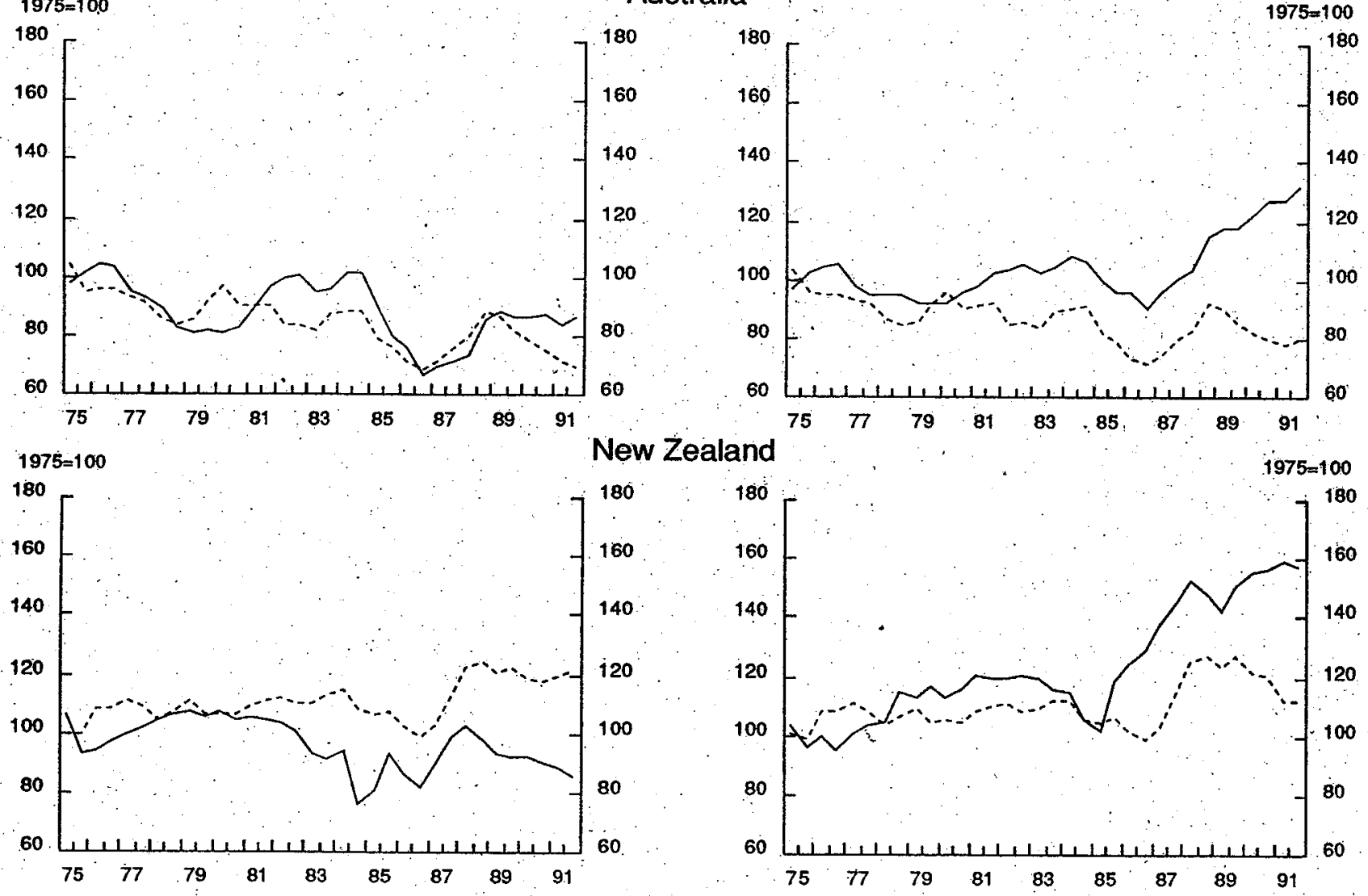
Chart A (cont'd).

\section{Overall competitiveness}
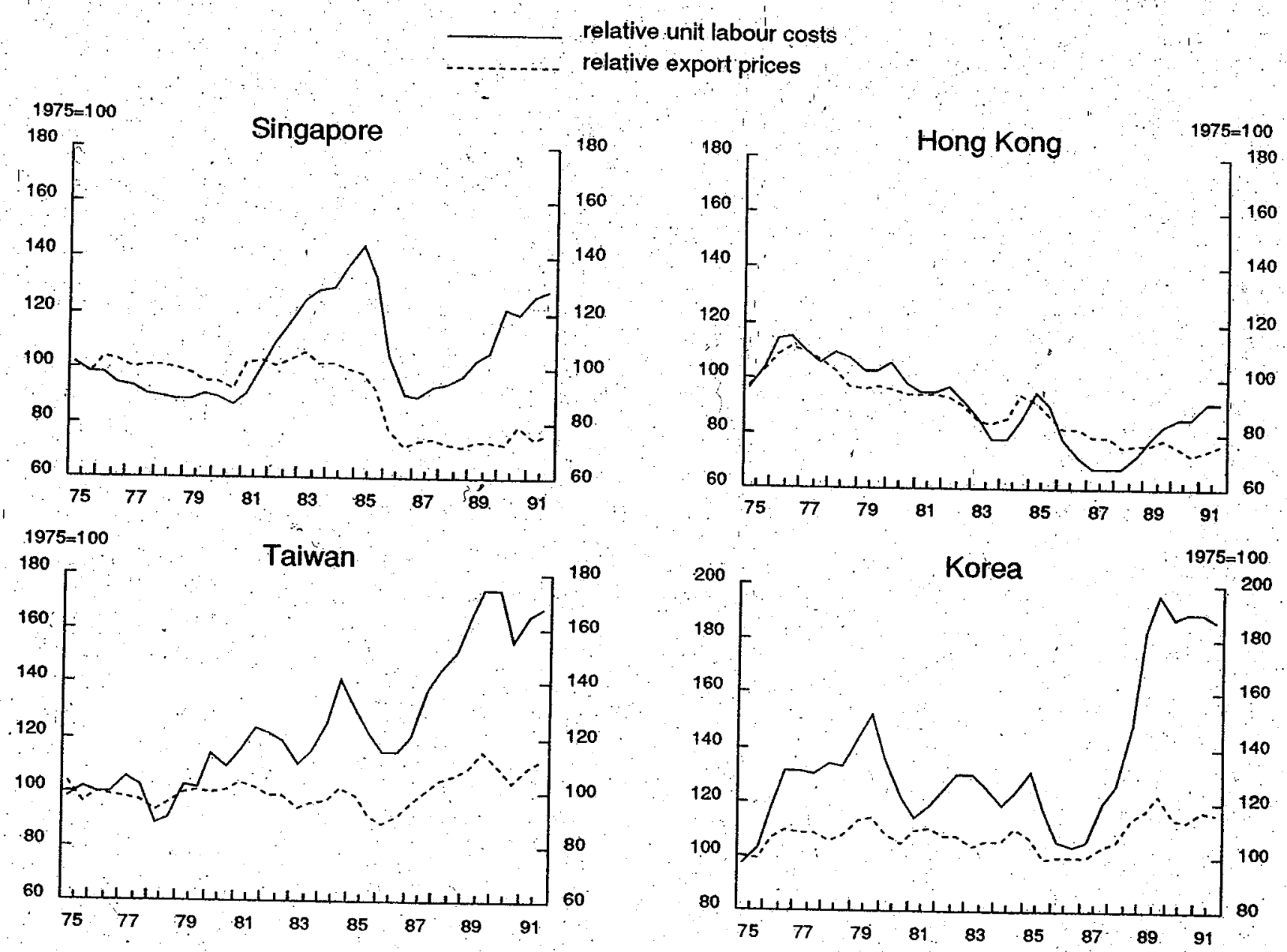
Netherlands have improved their relative competitive positions since 1985, while Denmark, Italy, Spain and Portugal have, registered a deterioration. In France, and to a lesser extent in Belgium, the decrease in relative unit labour costs since 1987 did not translate into lower relative export prices, as exporters seem to have rebuilt their comparatively low (by historical standards) relative profit margins.

987 The deterioration in the competitive position of the four DAEs since 1987 reflects rapid wage increases lalbeit from much lower levels than in $\mathrm{OECD}$ countries), and in the cases of Korea and Taiwan the appreciation of their
currencies.

The charts give the general impression that import competitiveness of almost all OECD countries had been on a deteriorating trend during most of the 1980s. This "puzzle" reflects the fact that inflation rates in total domestic demand deflators have tended to be larger than the rates of change in import prices: Using producer prices of value added in the manufacturing sector Unfortunatelyt domestic demand deflators may give more credible results. most o, thers are the price of srosies do not exist for some countries and for than domestic value-added.

\section{B. Indicators of export performance}

As mentioned in IIID above, traditional export volume equations, such as INTERLINK's, are specified in rates of change and include two main determinants: the change in price competitiveness, as described above, and the growth of export markets. Indicators of export market growth typically represent the potential for export growth in each country. A country's export which the defined as a weighted average of import volumes of all countries to shares detained by the country under study in weights represent the market shares detained by the country under study in each market (15), i e: :

$$
\mathrm{XVMKT}_{i}=\sum_{\mathrm{k}} \mathrm{m}_{\mathrm{ik}} \mathrm{MV}_{\mathrm{k}}
$$

where $\mathrm{XVMKT}_{i}$ is the export market of country $i$

$$
\begin{aligned}
& M V_{k} \text { is the total of imports (by volume) of country } k \\
& m_{i k} \text { is the market share of country } i \text { in } k^{\prime} \text { s total imports }
\end{aligned}
$$

Market growth indicators are then derived (see detailed calculations in Annex 1). For each country, they can be expressed as a weighted average of growth in all its markets' import volumes, the weighting pattern being derived from its export shares (16).

An indicator of export performance can then be calculated for each country by simply comparing the growth of its export volumes with that of its market. This shows whether each country's exports grow, faster or slower than losses. For all OECD countries, indicators thus defined are published in the growth and export performance changes in export market shares should be closely ric outlook. In principle, and cost competitiveness. A test of this hypothesis, for to changes in price over the period since 1975 , is presented in the next section. 


\section{Export competitiveness and export performance}

Fluctuations in price or cost competitiveness are not the only determinants of trade patterns. However, as indicated by chart $B$, there appears to be some correlation between movements in indicators of changes in (strictly defined) export competitiveness and market-share gains or losses in the manufacturing sector for a number of countries (after allowing for lag's). The sharp appreciation of the U.S. dollar in the first part of the $1980 \mathrm{~s}$ led to a deterioration of competitiveness which appears to be associated with market-share losses by the U.S. While the real effective depreciation of the dollar in the second part of the $198.0 \mathrm{~s}$ corresponds to a period of improvement in relative export competitiveness and substantial market-share gains. "In Japan, large market-share losses went along with the increase in relative export prices after 1985, which reflected the appreciation of the yen.

In Europe, correlations between export competitiveness and export performance seems to have been highest in Italy and Denmark. In Germany, the "link has been weaker since the start of the unification process, as domestic production has been diverted to satisfy the eastern German market, implying large export market-share losses. In a number of OECD countries (especially in Europe, but also in Canada) there seems to be a downward trend in the indicator of export performance.' This tends to reflect the loss of competitiveness of these countries vis-à-vis the DAE's.

Recent export performance of European countries has also been affected by market-share 1osses vis-à-vis Spain and Portugal, where important factors other than competitiveness were also at work in the latter part of the 1980 s; in particular EC entry and the subsequent large inflows of foreign direct investment. Despite a deterioration in their relative competitive position, market-share gains have been sustained, reflecting structural charges, notably a rise in the rates of return to productive capital. It has been noted that export growth has been particularly strong in sectors where there had been a concentration of foreign direct investment. Moreover, it should also be stressed that, although international comparisons are difficult to make, in absolute terms, costs and prices are probably still lower in spain and Portugal than in the majority of other OECD countries. 


\section{Chart B. EXPORT COMPETITIVENESS AND EXPORT PERFORMANCE}

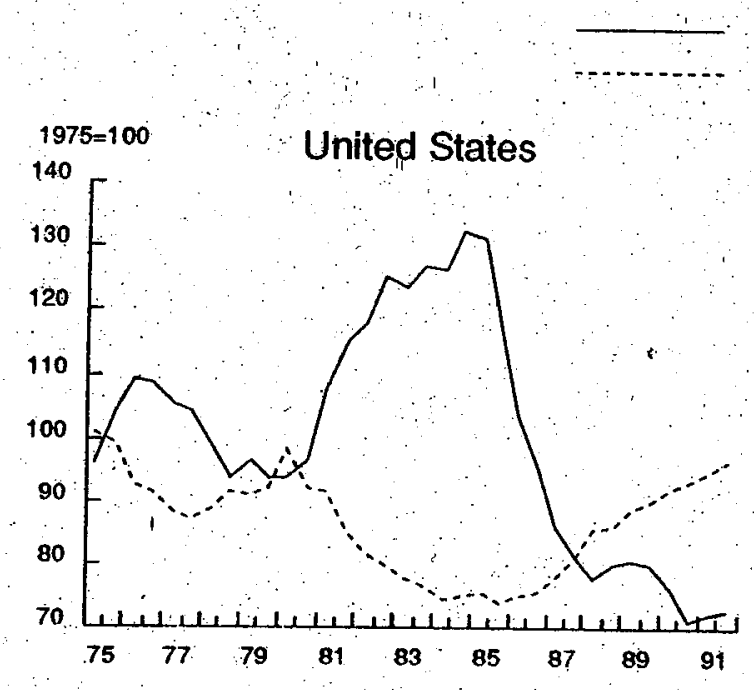

export competitiveness

export performance
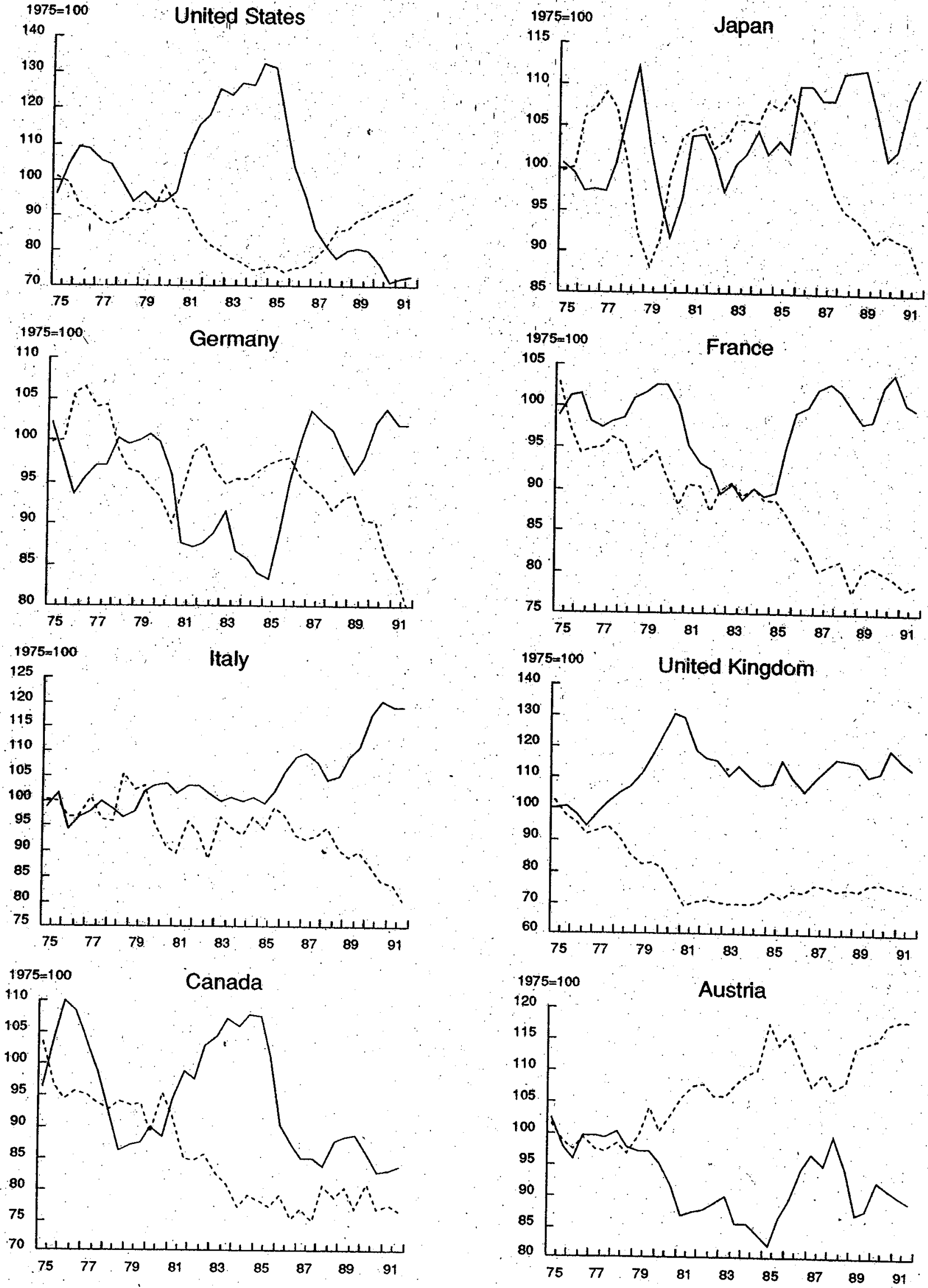


\section{Chart B (conit'd).}

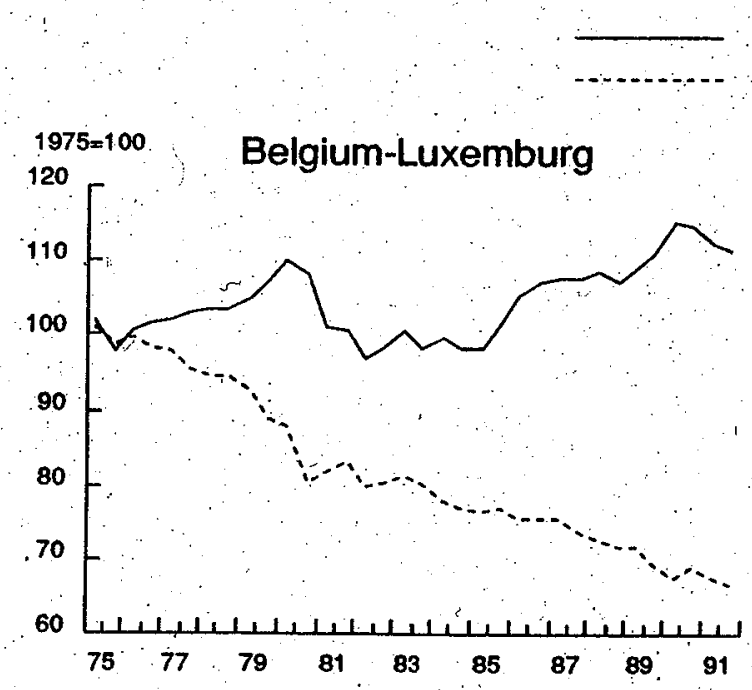

export competitiveness

export performance
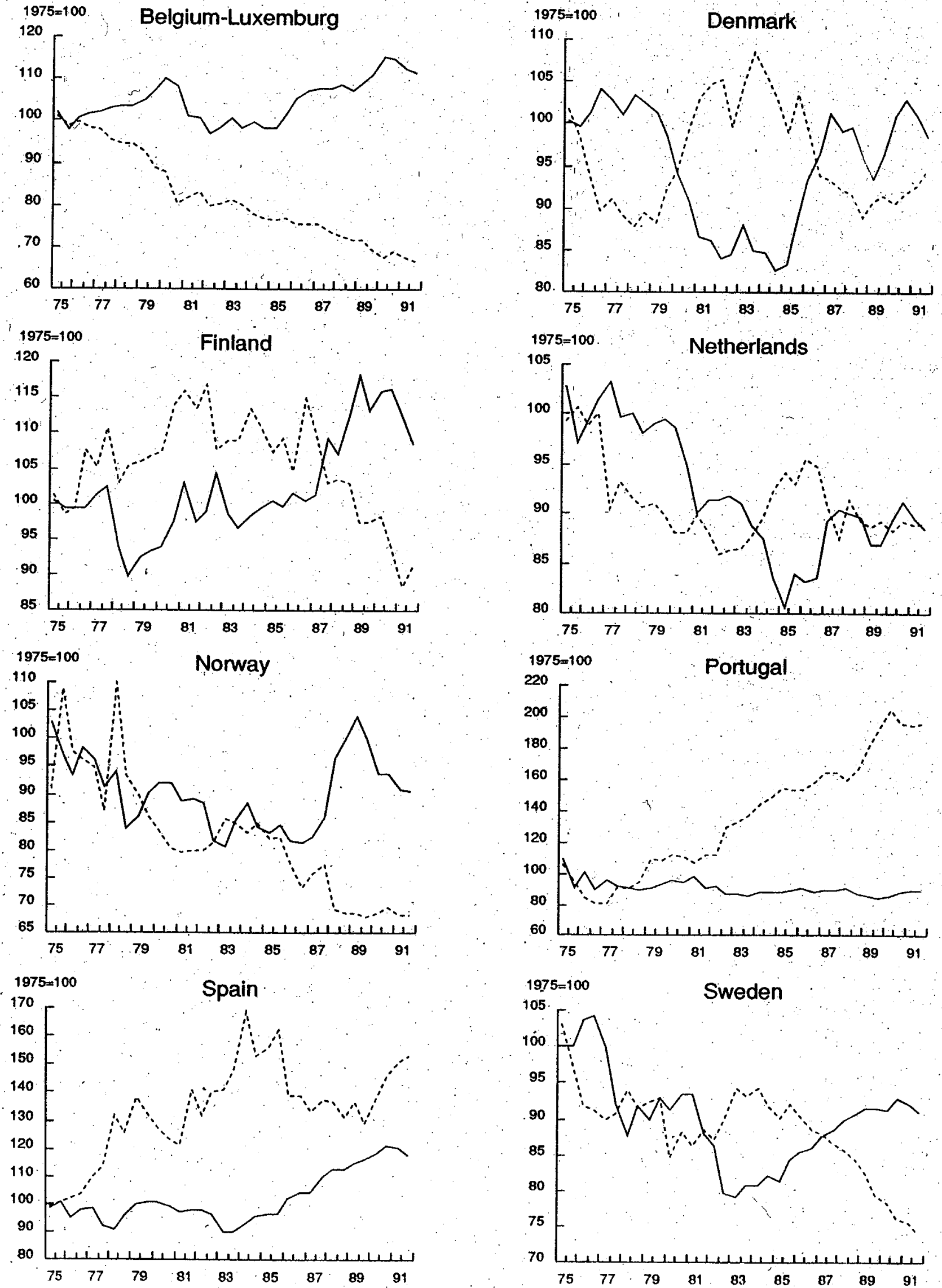
Chart B (Cont'd).

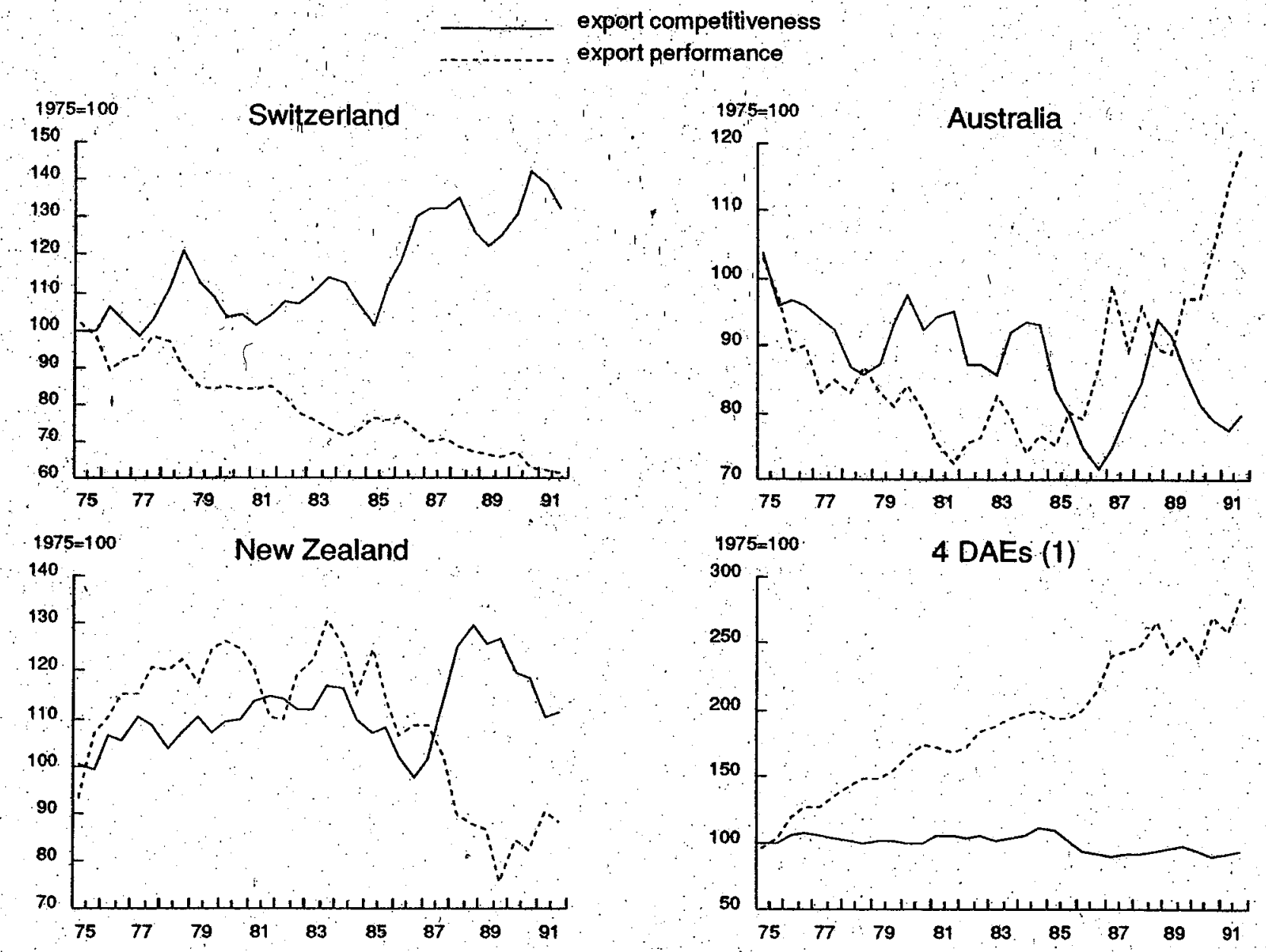

1. Export performance is only calculated for the aggregate zone which includes Korea, Hong Kong, Singapore and Taiwan. A composite relative export price for these countries is also shown for comparison. 
1. The authors would like to acknowledge the comments and suggestions of Nick Vanston, Mike Feiner and Pete Richardson.

2. Belgium for instance, in its law on competitiveness, assesses Belgium's export performance relative to its five main European competitors.

3. For a discussion of the choice of indicators and their limitation, see Durand, $M$. and C. Giorno "Indicators of international competitiveness: conceptual aspects and evaluation", OECD ECOnomic studies No 9, Autumn 1987.

4. Indicators of relative unit labour cost or relative export prices are in fact measures of real effective exchange rates, as they can be expressed as the ratio of nelative nominal exchange rates to relative costs or prices expressed in local currency. See Durand, M. and. C. Giorno, (1987).

5. For the breakdown of non-OECD countries into these six groupings, see OECD EConomic Outlook, "Sources and Methods".

6. The following nineteen OECD countries for which homogeneous cost data are available are included in the calculations: United States, Japan, Germany, France, United Kingdom, Italy, Canada, Australia, Austria, Belgium, Denmark, Finland, Netherlands, New Zealand, Norway, Portugal;, Spain, Sweden, Switzerlard. The four Dynamic Asian Economies included are Taiwan, Hong Kong, Singapore and Korea.: (Malaysia and Thailand are excluded because of data problems.)

7. The equations are specified in terms of changes in competitiveness and the resulting indicators are this: expressed in terms of price changes. (Here and from now on, the term "export price" should be understood to refer to export unit values for manufactured goods). The prices given here are hence expressed as growth rates, and will be thus expressed henceforth. This implies that the weighted average is a geometric average. Relative to the other options (arithmetic; harmonic, etc.), the latter is the only one that provides a certain number of basic properties (for more details, see Pinçon, 1979).

8. Government wáges are in fact excluded from the total domestic demand deflators.

9. This assumption, which implies no pricing difference by exporters on their different markets, is rendered necessary by the lack of availability of bilateral trade prices. 10. These indicators are published twice yearly in the OECD Economic
Outlook. 
11. The INTERLINK specification also has implications for the deftnition of the market growth variables entering the export volume equations. Market growth in this case is calculated as a weighted average of import volumes of each market (see part III). By contrast, if export volume equations were to be estimated using measures of broadly-defined export competitiveness, market growth variables would have to be defined as a weighted average of supply (volume of import and output) in each market. Because data on manufacturing supply are more difficult to obtain on a comparable basis, international trade models generally follow the INTERLINK approach.

12. See Artus and Rhomberg (1973).

13. See OECD EConomic Surveys, Japan $1990-91$.

14. Markets for each country are sometimes defined as the world market. It is assumed here that countries do not all face the same foreign demand, hence the approach followed.

15. The derivation of market shares necessitates matrices of bilateral trade. The latest such available matrix is for the year 1987 . The $m_{i k}$ are therefore market shares for that year.

16. The weighting pattern is not exactly identical to a country's export structure at any time but is a close approximation. See Annex l- for details. 
ARMINGTON, P. (1969), "A theory of demand for products distinguished by place of production", International "Monetary. Fund Staff Papers, March, pp. $159-17.5$.'

ARMINGTON, P. (1969a), "The geographic pattern of trade and the effects of price changes", International Monetary Fund Staff Papers, July, pp. 179-199.

ARTUS, J. and RHOMBERG, R, (1973), "A multilateral exchange rate model", International Monetary Fund Staff, Papers, November, pp: 591-611.

BANK of ENGLAND (1982), Measures of competitiveness, Quarterly Bulletin, 1. September, pp. 369-375.

BELONGIA, M. (1986), "Estimating exchange rate effects on exports: " a cautionary. "note", Federal Reserve Bank of Saint-Louis, January, pp. $5-16$.

BUNDESBANK (1989), "Revision of the method of calculating the external value of the Deutsche Mark and foreign currencies", Monthly Report, April, pp. $43-50$.

DEBONNEUIL, M. and DELATTRE, M. (1987), "Le commerce extérieur de la France: une théorie pour la pratique", INSEE, March.

DURAND, M. (1986), "Method of calculating effective exchange rates and indicators of competitiveness", OECD Department of Economics and Statistics Working Paper No $2 \dot{9}$, February.

DURAND, M: and GIORNO, C. (1987) "Indicators of International Competitiveness: Conceptual Aspects and Evaluation", OECD Economic Studies, No 7, Autumn.

Economie Européenne (1985), No 25, Septembér.

Economie et Prévịsion (1990), No 94-95.

ETIENNE, PINÇON, FARKAS and LACLAIRE (1980), "Une méthode de mesure de la compétitivité internationale des produits français", Bulletin Trimestriel de la Banque de France, March, pp. 19-31.'

FEDERAL RESERVE BOARD (1985), "Index of the weighted average exchange value of the U.S. dollar: revision", Builetin, November, pp. 700-701.

FEDERAL RESERVE BOARD (1987), "Measuring the foreign exchange value of the dollar", Bulletin, June, pp. 411-422.

FELDSTEIN, M. and BACCHETA, P. (1987), "How far has the dollar falien?", National Bureau of Economic Research Working Paper No 2122, January. 
HERD, R. (1987), "Import and export price equations for manufactures", OECD Department of Economics and Statistics Working Paper No 43, June.

HICKMAN, B. and LAU, L. (1973), "Elasticities of substitution and export demands in a world trade model", European Economic Review, December, pp. $350-380$.

HIRSCH, E. and HIGGINS, I. (1970), "An indicator of effective exchange rates", International Monetary Fund Staff Papers, November; pp. 453-487.

H.M. TREASURY (1977), "The effective exchange rate for sterling", Economics. progress Report, March; pp. 1-3.

H:M. TREASURY (1981), "The effective exchange rate for sterling", Economics Progress Report, February; p. 7 .

H;M: TREASURY (1984), "Sterling exchange rate index", Economic Progress Report, october, pp. 1-2.

MACIEJEWSKI, E. (1983), "Real effective exchange rate indices. A re-examination of the major conceptual and methodological issues", International Monetary Fund Staff Papers, September, pp. 491-541.

MORGAN GUARANTY TRUST (1983), "Effective, exchange rates: update and refinement", World Financial Markets, August, pp. 6-14.

MORGAN GUARANTY TRUST (1986), "Dollar index confusion", World Financial Markets, October-November, pp. 14-17.

OECD (1978), "The international competitiveness of selected OECD countries", occasional Studies, July, pp. 35-50.

OECD (1991), Economic Survey of Spain, 1990/1991.

PINÇON, R: (1979), "Réflexions méthodologiques concernant les calculs de taux de change pondérés et d'indices de compétitivité", Cahiers économïques et monétaires de la Banque de France, February, pp. 89-107.

RHOMBERG, R. (1976), "Indices of effective exchange rates", International Monetary Fund Staff Papers, March, pp. 89-112. 


\section{DERIVATION OF MARKET GROWTH AND EXPORT PERFORMANCE INDICATORS}

For all OECD countries, the secretariat calculates market growth and export performance indicators for 4 groups of commodities, which cover SITC categories $0-1,2-4,3,5-9$, and for the total of merchandise (SITC $0-9$ ). This Annex provides the details of such calculations.

\section{EXPORT MARKETS}

A country i's export market for each group of commodities (SITC $0-1,3$, 2-4 and 5-9), excluding the merchandise total (SITC $0-9$ ) is defined in the following way:

Let XLikT be the $(i, k)$ th element of a trade matrix, i.e the exports of commodity $L$ from country $i$ to country $k$ expressed in U.S. dollars in a given year $T$ (1).

Country i's export market for commodity $\underline{L}$ in period $t$ is defined as:

$$
\mathrm{XLVMKT}_{\text {it }}=\sum_{\mathrm{k}}\left(\mathrm{WL}_{\mathrm{ikT}} * \mathrm{MLV}_{\mathrm{kt}}\right)
$$

where the MLVkt are imports of commodity $L$ by country $k$ in period $t$, expressed in constant U.S. dollars.

$$
\text { and } W_{\text {Likt }}=\frac{X_{\text {LikT }}}{\sum X_{i} \mathrm{XLKT}}
$$

WLikT represents country i's market share in country $k^{\prime} s$ imports of commodity $\underline{L}$ in the reference year $T$..

For the total of goods, country's $i$ export market is defined as:

$$
\text { XGVMKTIt }=\sum_{\underline{L}=1}^{4} \text { XLVMKT }_{\text {it }}
$$


Country $i$ export market growth for each group of commodity $L$ is defined

$$
\begin{aligned}
& \text { XLMGRWTH }_{i t}=\text { XLVMKT }_{i t}-\text { XLVMKT }_{1} t-1 \\
& \mathrm{XIVMKT}_{i} t-1
\end{aligned}
$$

or:

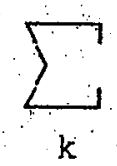

$$
\frac{\text { WLikT * (MLVikt } \left.-M L V_{k} t-1\right)}{\sum \text { WLikT * MLVk } t-1}
$$

which can be rewritten in the following way:

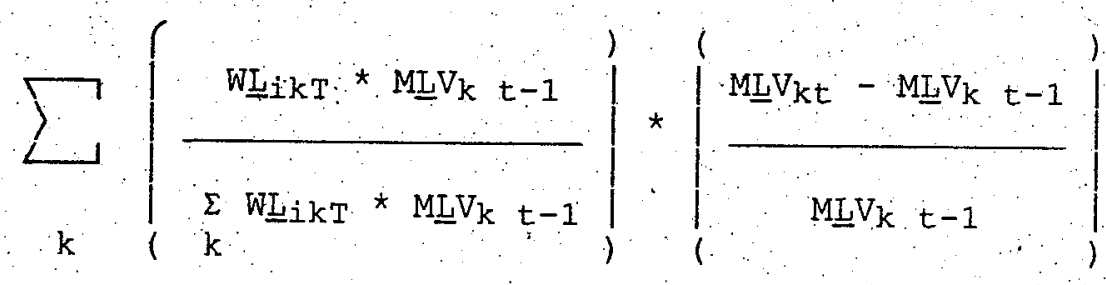

i.e.:

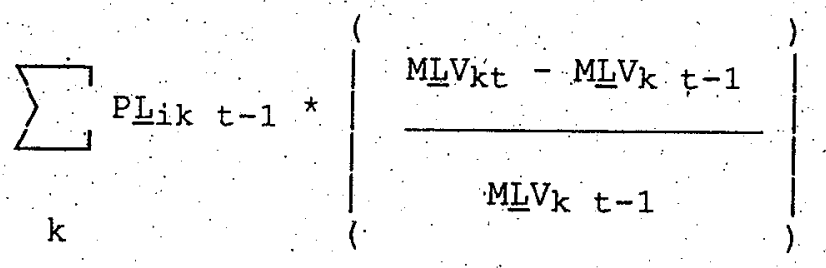

Country i's export market growth for groups of commodities $L$ is thus equal to a weighted average of growth in all countries $k^{\prime} s$ imports of commodity $\underline{L}$.

The weights used in the calculation are equal to:

$$
\text { PLik } t-1=\frac{W L_{i k T} * M L V_{k} t-1}{\vdots \sum_{k} W_{i k T} * M L_{k} t-1}
$$

and represent country $i^{\prime}$ s export share of commodity $L$ to country $k$ in the total of country i's exports of commodity $L$ using the market pattern of the reference year $T$. This structure is however adjusted in each period to take account of changes. in markets relative to year. $T$, in the following way: 
Replacing "Wikt by its value leads to:

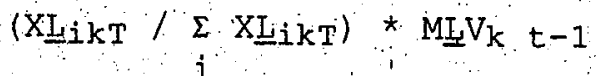

PLik $t-1=$

$$
\sum_{k}\left(X_{L_{i k T}} / \sum_{i} X_{L i k T}\right) * M V_{k} t-1
$$

Noting that $\Sigma$ XLikT $=$ MLkT, one gets:

$$
\text { i, }
$$

$$
\operatorname{XLikT}_{\text {i }} *\left(\frac{M L_{k} t-1}{M L_{k T}}\right)
$$

PLik $t-1:=$

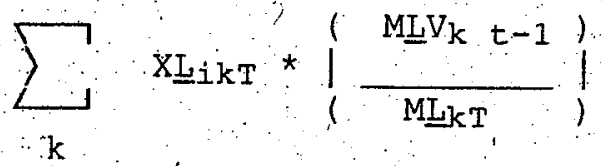

When calculations are done on an annual basis, in year $T+1$ $\mathrm{MLV}_{k} t-1=\mathrm{ML} \underline{k}_{\mathrm{T}}$, and hence:

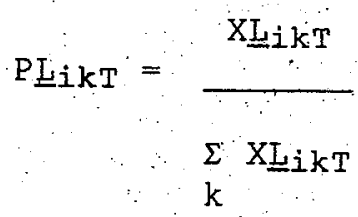

i.e. in that case PLikT represents country $i^{\prime} s$ export pattern of comodity $\underline{L}$, according to the country of destination $k$.

Export market growth of total goods equals:

XGMGRWTH $_{i t}=\frac{\text { XGVMKT }_{\text {it }}-\text { XGVMKT }_{1} t-1}{\text { XGVMKT }_{i} t-1}$

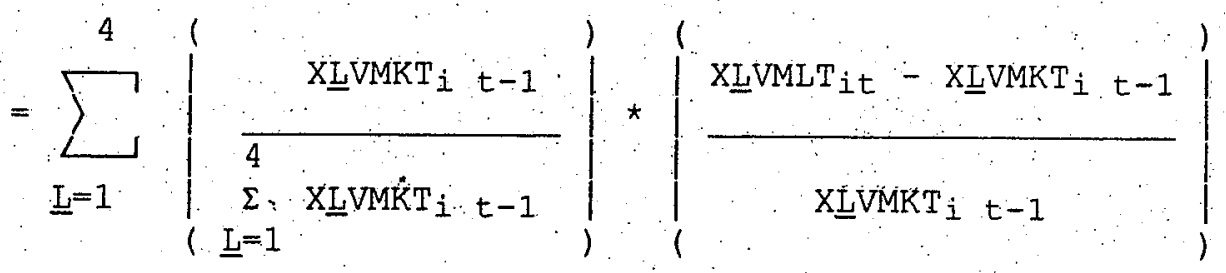

i.e. it is the weighted average of export market growth of the 4 groups of commodities with weights equal to the share of each group of commodities market in country i's total export market in period $t-1$. 


\section{EXPORT PERFORMANCE}

From market growth indicators calculated above, export performance indicators are derived for each group of commodities in the following way:

XLPERF it $=X_{\text {XLV }} / \mathrm{XLVMKT}_{\text {it }}$

where $X_{L V}$ it represent country $i^{\prime}$ s exports of comodity $\underline{L}$ in period $t$

This indicator is a measure of the gap between a country's "potential" and actual exports. Changes in the indicator illustrates market-share gains or losses for each group of commodities $I$ :
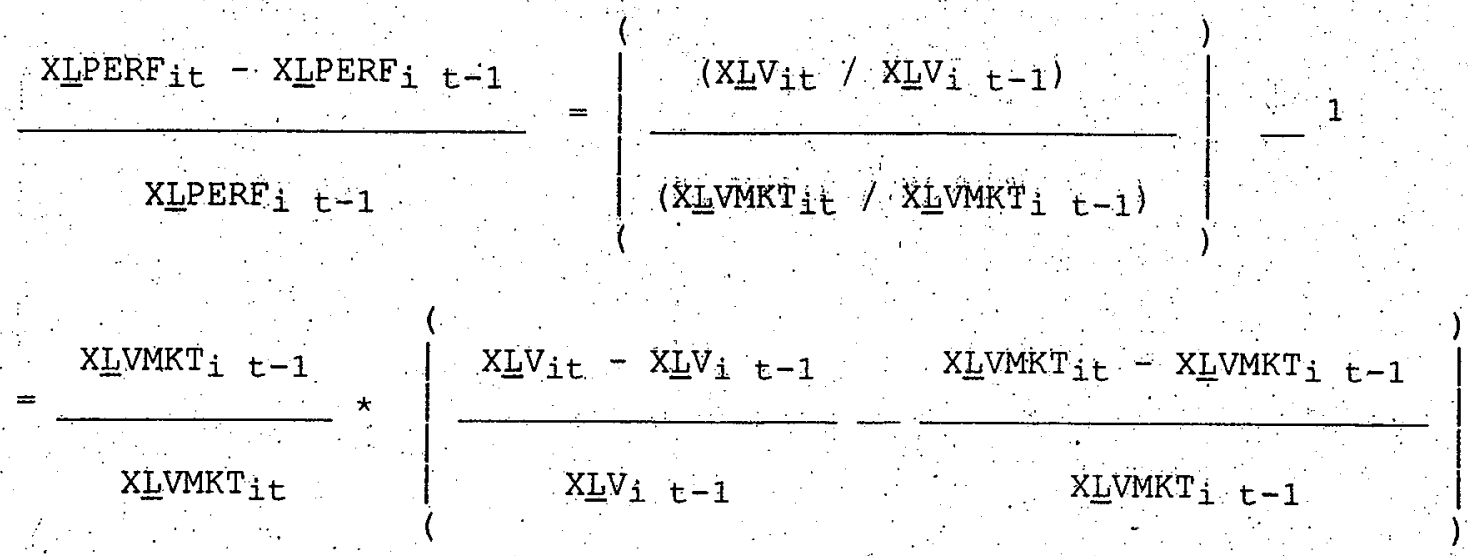

The change in export performance is therefore the difference between country i's export volume growth and its export market growth, adjusted for the change in the size of its market.

$$
\therefore
$$

NOTES

1. Currently the reference year is 1987.

2. $\because$ This adjustment consists in estimating an implicit trade flows matrix in each period $t$, by assuming that country i's exports to market $k$ grow at the same rate as all exports to market $k$. 
Annex 2

\section{SOURCES AND METHODS FOR THE SERIES USED TO CALCULATE INTERNATIONAL TRADE AND COMPETITIVENESS INDICATORS}

\section{INTERNATIONAL TRADE: VALUES, VOLUMES AND PRICES}

\section{A. General Methodology}

The data used to calculate foreign trade values, volumes and prices are usually, those supplied by countries, except in the case of Iceland and Turkey, for which national series are not available; these are thus estimated from the foreign trade data of the other countries. "In most instances, the data: supplied comprise series on import and export values and volumes for the following five SITC categories (1):

1. Food and live animals, beverages and tobacco ( $S$ ITC sections $0+1$ );

2. Mineral fuels, lubricants and related materials (SITC section 3);

3. Crude materials, inedible, except fuels, animal and vegetable oils, fats and waxes (SITC sections $2+4$ );

4.. Chemicals, manufactured goods, classified chiefiy by material, machinery and transport equipment and miscellaneous manufactured articles (SITC sections $5-9$ );

5. Total goods

(SITC sections $0-8$ or $0-9$ according to country).

From these series, average unit value (price) indices are calculated as value/volume ratios: For a number of small countries, the national data are not on a quarterly basis and/or do not correspond to the classification by 5 broad SITC product categories. Moreover, depending on the country, the data supplied to the Foreign Trade and Investment (FTI) Division of the Economics Department are either seasonally adjusted or unadjusted. The first task of the FTI Division is therefore to render homogeneous all the country data according to the following step-by-step procedure:

1. If the periodicity of the national series is other than quarterly, quarterly value and volume series are calculated, úsing a method specific to each country (see B).

2. Seasonally adjusted series are derived from these value and volume series. 
3. Seasonally adjusted price series (average unit values) are then obtained from the ratios of the value to the volume series calculated in step 2:

4. Where the data supplied are more highly disaggregated than required, or the national classification is different from the SITC, series aggregated according to the 5 SITC product categories are calculated

5. Volumes are then expressed on the base 1987, while prices are converted to price indices (also $1987=100)$ in local currency.

Whereas steps 1 to 5 above are the usual procedure for processing the basic data, there are methodological features specific to each country, which are described in the following section.

\section{B. Sources and methodological features by country}

Annex 3 contains the names and addresses of the national statistics institutes supplying foreign trade figures directly to the FTI Division or to the Statistics Directorate (SD). This last publishes monthly foreign trade figures (Monthly Statistics of Foreign Trade - - Series A). Part 3 of this publication gives, for 20 Member countries, import and export values expressed in U.S. dollars for the 5 broad product categories defined above, on the basis of data supplied by national. statistics institutes at lower order SITC levels. The Statistics Directorate also publishes average volume and value indices on the base 1985=100 for a number of products grouped according to classifications varying across countries (SITC, or according to raw material, type of use, degree of processing, etc.). As a general rule, to avoid duplication of effort, whenever data from national statistics institutes are processed by the Statistics Directorate according to one or more of the steps described in Section A, these are used directly by the FTI Division. Similarly, when, for some countries, elements needed to process the data are lacking, wherever possible the foreign trade indicators calculated by the statistics Directorate are used.

\section{United States}

The data are seasonally adjusted import and export values and volumes expressed in U.S. dollars supplied by the U.S: Department of Commerce for all the product categories except for "raw material and energy exports. Save for this last group, prices are estimated by the value/volume ratios.

For exports of raw materials and energy, the national data are not available separately but as a single aggregated series. The separate series are derived as follows:

-- Energy export prices are estimated by the FTI Division on the basis of International Energy Agency data.

-- Energy export volumes are derived by combining the above prices and the value series corresponding to SITC section 3 supplied by the Statistics Directorate. 
- Export volumes for raw materials are derived by calculating the difference between the aggregated export series (raw materials + energy) of the U.S. Department of Commerce and the energy exports series calculated above.

-- Raw material export values are supplied by the statistics Directorate.

-- Raw material export prices are then estimated by the corresponding value/volume ratios.

\section{Japan}

The data are unadjusted import and export volume and price indices aggregated by the Statistics Directorate on the basis of Japan Tariff Association data for each SITC product category.

Prices and volume data for energy exports (which account for only a small proportion of total Japanese exports) are, however, not available. As an approximation, energy export prices are assumed to be equal to energy import prices and energy export volumes are derived from this price series and a value series provided by the Statistics Directorate.

Value indices are abtained by calculating the products of the volume and the average value indices. The values and volumes are then seasonally adjusted and the prices are estimated by the value/volume ratios.

\section{Germany}

$\therefore$ The national data are the Deutschemark values of imports and exports in 1985, and the unadjusted volume and average value indices aggregated by the Statistics Directorate from Statistisches Bundesamt data for each product category.

Since data prior to 1991 relate only to western Germany and thereafter data relate to unified Germany, there is a break in the series supplied between 1990 and 1991. In order to obtain a series for unified Germany spanning the whole period, the followed method was employed:

1. Unadjusted Deutschemark values and volumes are derived from the data supplied.

2: The values and volumes for years prior to 1991 (i.e. data for western Germany only) are seasonally adjusted.

3. Seasonaliy adjusted data for 1991 are obtained by applying the seasonal factors calculated in step 2 .

4. Two time series for intra-Germany trade, one for all exports and the other for all imports, are estimated by the FTI Division. These series are used to adapt the seasonally adjusted value and volume data calculated in step 2 to give the data for unified Germany prior to 1991 . 
5. The seasonaliy adjusted prices are then estimated by the value/volume ratios calculated above,

\section{France}

The national data are seasonally adjusted French franc export and import talues and volumes for the 5 product categories supplied by the Institut National de la Statistique et des Etudes. Economiques (INSEE) :

The prices are calculated from the value/volume ratios.

\section{Italy}

The national data are Italian lira values and unadjusted volume indices aggregated by the Statistics Directorate on the basis of Istituto Centrale di Statistica (ISTAT) data for imports and exports of the 5 product categories.

The values are first converted to value indices; the value and volume indices are then seasonally adjusted and the prices are estimated by the
value/volume ratios.

\section{United Kingdom}

The national data are seasonally adjusted pound sterling values and volumes supplied by the Central Statistical office (CSO) for imports and
exports of the 5 product categories.

The prices are calculated from the value/volume ratios.

\section{Canada}

The national data are seasonally adjusted Canadian dollar values and volumes supplied by Statistics Canada for imports and exports of the 5 product
categories.

The prices are calculated from the value/volume ratios.

\section{Australia}

The national data are seasonally adjusted Australian dollar values and volumes supplied by the Australian Bureau of Statistics for imports and exports of the 5 product categories

The prices are calculated from the value/volume ratios.

\section{Austria}

The national data are unadjusted values in Austrian Schilling and volume indices, aggregated by the Statistics... Directorate on the basis of Österreichisches Statistisches Zentralamt data to obtain imports and exports of
the 5 product categories. 
Volumes in Austrian Schilling are derived from the national data. The values and volumes are then seasonally adjusted and used to calculate the prices.

\section{Belgium/Luxembourg.}

Up to end-1987, the national data are unadjusted volume indices for all traded goods and manufactures and unadjusted value series in Belgian/Luxembourg francs for the flve SITC product categories, calculated by the statistics Directorate from Institut National de statistique data.

The export and import prices for all goods and for manufactures are derived directly from the above national series..'

Export and import prices for food, energy and raw materials are estimated prior to 1988 as the geometric mean of the corresponding prices of Germany, France, Italy, the Netherlands and the United Kingdom, weighted by these countries" GDP. "Volumes are estimated by the value/price ratios.

From the beginning of 1988 onwards, the data are unadjusted volume and and price indices supplied by the Banque Nationale de Belgique. These series are used to supplement the value and volume data calculated as described above for earlier years.

The value and volume data are then seasonally adjusted and the prices derived therefrom.

\section{Denmark}

The data are the Danish kroner values for 1985, as well as unadjusted volume and price indices supplied by Danmarks Statistik for imports and exports of the 5 product categories.

The Danish kroner values and volumes are derived directly from the national data. The series are then seasonally adjusted and the prices calculated from the value/volume ratios.

\section{Finland}

The data are annual value and volume indices for imports and exports broken down by the 5 broad SITC categories and supplied by the National Board of Customs (NBC), quarterly values in Finnish markkaa and quarterly volume indices calculated by the Statistics Directorate on the basis of NBC data. The quarterly value data are broken down according to the SITC. Such is not the case of the quarterly volume data.

The unadjusted quarterly series of the Statistics Directorate are used to convert the annual NBC data to quarterly figures by means of the procedure outlined below:

1. The Statistics Directorate's value data are used to convert the corresponding NBC annual data to quarterly figures. 
2. The statistics Directorate's volume data are used to convert the corresponding NBC annual data to quarterly figures, using the following equivalence table:

\section{a) Imports}

Quarterly basis for interpolation (SD)

Total goods

Crude materials and related. materials

+ crude materials for industry.

+ construction

1. Fuels and Lubricants

, Consumer goods

+ investment goods

b) Exports

Quarterly basis for
interpolation (SD)

Total goods

Forestry products

Energy values/average value index

Total goods
Annual data to be converted

to quarterly (NBC)

Food

Raw materials

Energy

Manufactured goods

Annual data to be converted to quarterly (NBC)

Food

Raw materials

Energy

Manufactured goods

3. The quarterly value and volume data thus constructed according to SITC category are then seasonally adjusted and the prices estimated by the value/volume ratios.

\section{Greece}

The data are 1985 Greek drachma values as well as unadjusted volume and value indices aggregated by the statistics Directorate on the basis of data supplied by the National Statistical Service of Greece to obtain imports and exports of the 5 product categories.

The values and volumes in Greek drachmas, directly derived from these series, are then seasonally adjusted and the prices estimated by the value/volume ratios.

\section{Turkey and Iceland}

National volume and price series are not available for these countries,

Value data (in U.S. dollars) for "food", "energy", "raw materials" and "manufactured goods" are calculated from annual statistics. Directorate data - (Foreign Trade by Commodities - - Series C, compatible with Series A but on an annual basis only).

These annual values are converted to quarterly series using as benchmarks "for interpolation the seasonally adjusted import/export data 
(customs basis) published in the OECD's Main Economic Indicators. The quarterly U.S dollar values for the 4 product categories are then converted into local currency and the quarterly values 'for "total goods" obtained by summation.'

For each of the 4 product categories, quarterly export price indices are estimated using the geometric mean of the import price indices of 18 OECD countries, weighted by the levels of 1987 exports of Turkey/Iceland to these dountries.

Quarterly import price indices are estimated in similar fashion, using the export price indices of the same 18 countries.

Quarterly import and export volumes for the 4 product categories are obtained from the corresponding value/price ratios, and quarterly volumes for "total goods" calculated by sumation.

The quarterly import and export prices for "total goods" are derived from the corresponding values and volumes.

\section{Ireland}

The national data are the unadjusted values aggregated by the Statistics Directorate on the basis of Central statistical Office (CSO) data and CSO unadjusted price indices for imports and exports of the 5 product categories with the exception of energy export prices which are assumed to be equal to energy import prices.

The unadjusted volume series are derived directly from the above national data. The values and volumes are then seasonally adjusted and the prices calculated therefrom.

\section{New Zealand}

The national data are the 1985 values in New Zealand dollars, as well as the unadjusted average volume and value indices aggregated by the statistics Directorate on the basis of Department of statistics data to obtain imports and exports of the 5 product categories.

Values and volumes in New Zealand dollars are derived from these national series. The series are then seasonally adjusted and the prices estimated by the value/volume ratios.

\section{Netherlands}

The data are annual volume and price indices for the 5 SITC product categories supplied by the Central Planning Bureau, as well as quarterly value data in guilders and seasonally adjusted price indices supplied by the Centraal Bureau voor de Statistiek (CBS) from which quarterly volume series are calculated.

However, CBS data are not broken down by SITC section and the following method is hence employed to obtain quarterly series on an SITC basis: 
- the export and import volume and price data for "total goods" and "energy" are obtained directly from the CBS data;

- the other export volume and price data, 1.e for "food", "raw materials" and "manufactured goods", are derived from the corresponding annual Central Planning Bureau series, using the CBS volume and price series for "total goods minus energy" to interpolate them to quarterly figures;

- the import volume and price data for "food", "raw materials" and "manufactured goods", are also derived from the corresponding annual Central Planning Bureau series, but this time by using the "consumer goods" and "raw materials and semi-finished goods" series as well as the sum of CBS figures for "investment goods" and "consumer goods" to

1 obtain quarterly figures.

\section{Norway}

The national data are unadjusted volume and average value indices aggregated by the Statistics Directorate on the basis of Statistisk Sentralbyra data for imports and exports of the 5 product categories.

Value indices are obtained by calculating the products of the volume and the average value indices. The values and volumes are then seasonally adjusted and the prices estimated by the value/volume ratios:

\section{Portugal}

$\therefore$ The data are unadjusted values and volumes in portuguese escudos, supplied by the Ministério do Comércio e Turismo for imports and exports of the 5 product categories.

These values and volumes are then seasonally adjusted and the prices derived therefrom.

\section{Spain}

The national data are values in spanish pesetas and seasonally adjusted volume indices from the Ministero de Economia y Hacienda for imports and exports of the 5 product categories.

The prices are calculated from the value/volume ratios.

\section{Sweden}

The national data are values in Swedish kronor and unadjusted volume indices, aggregated by the Statistics Directorate on the basis of Statistics Sweden data to obtain imports and exports of the 5 product categories.'

The volumes in Swedish kronor are derived from the national data. The values and volumes are then seasonally adjusted and the prices calculated therefrom. 


\section{Switzerland}

The national data are unadjusted volume and price índices supplied by Konjunkturforschungsstelle for exports and imports of "total goods.", "energy", "raw materials" and "manufactured goods". Energy export prices, however, are not available and are assumed to be equal to energy, import prices.

Exports and imports of "food" are estimated by the FTI Division on the basis of data published in La Vie Economique (office fédéral de l'industrie, des arts et métiers et du travail).

The value series are derived directly from the above national series. The values and volumes are then seasonally adjusted and the prices derived therefrom.

\section{Foreign trade prices and volumes for the 6 non-OECD geographical areas}

For the most part, the foreign trade data for the non-OECD areas are supplied by the World Bank. The data are annual export and import value and price series for the 5 product categories, expressed in U.S. dollars. Volume series on a constant 1987 dollar basis are derived from these series. All the series are then interpolated with a time trend so as to obtain quarterly figures. For the areas comprising the Central and Eastern European countries and the Newly Industrialised Economies, data from national statistical institutes are also used for purposes of interpolation.

\section{UNIT LABOUR COSTS IN MANUFACTURING}

For the seven major OECD countries and four small OECD countries (Belgium, Netherlands, Sweden and Denmark), data on unit labour costs in manufacturing are provided by the Bureau of Labour statistics (BLS) which constructs homogeneous and comparable country series on the basis of annual national data.

In the case of Austria, Norway, Portugal and Australia, the quarteriy data are supplied directly by national institutes (WIFO, Norges Bank, Instituto Nacional de Estatistica and Australian Bureau of Statistics, respectively). In the case of Switzerland and Finland, annual data are supplied by the national statistics institutes, while in that of Spain and New Zealand quarterly data are estimated by the OECD from unit labour costs for the whole economy excluding the government sector:

For countries for which only annual series are available, the data are interpolated in order to convert them to quarterly figures. In general, this interpolation is done on the basis of series on wages, employment and volume output in manufacturing or, in the case of some countries, a broader sector (non-agricultural: for example) for which quarterly series are available, but which cannot be used directly because the definition of the sector varies across countries.

For the Newly Industrialised Economies, the unit labour costs series are calculated from data on employment, volume output and wages in manufacturing supplied by the IMF (International Financial Statistics) for the . Republic of, 
Korea, the national statistics institute for Taiwan, the International Labour office and national sources for Hongkong, and the IMF and national sources for Singapore:

\section{NOTES}

1. In the interests of simplicity, SITC Section $0+1$ is denoted in this study by "food", SITC 3 by "energy", SITC $2+4$ by "raw materials", SITC 5-9 by "manufactured goods" and SITC 0-9 by "total goods".

2. These six geographical areas are: OPEC; the Newly Industrialised Economies (NIES), Asia (excluding OPEC and NIEs) and the rest of Oceania, Latin America (excluding OPEC), Africa (excluding OPEC), and the Central and Eastern European countries. 


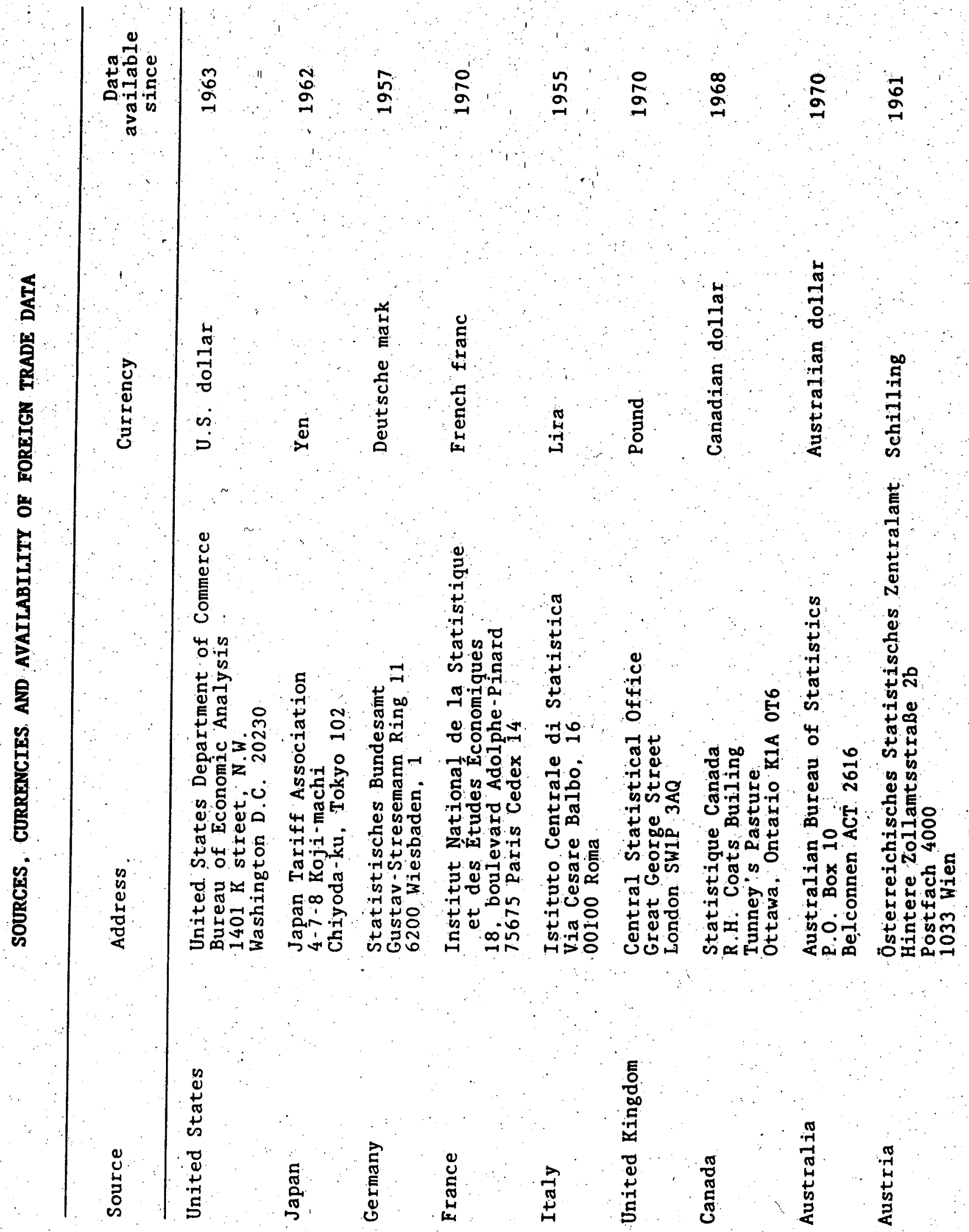




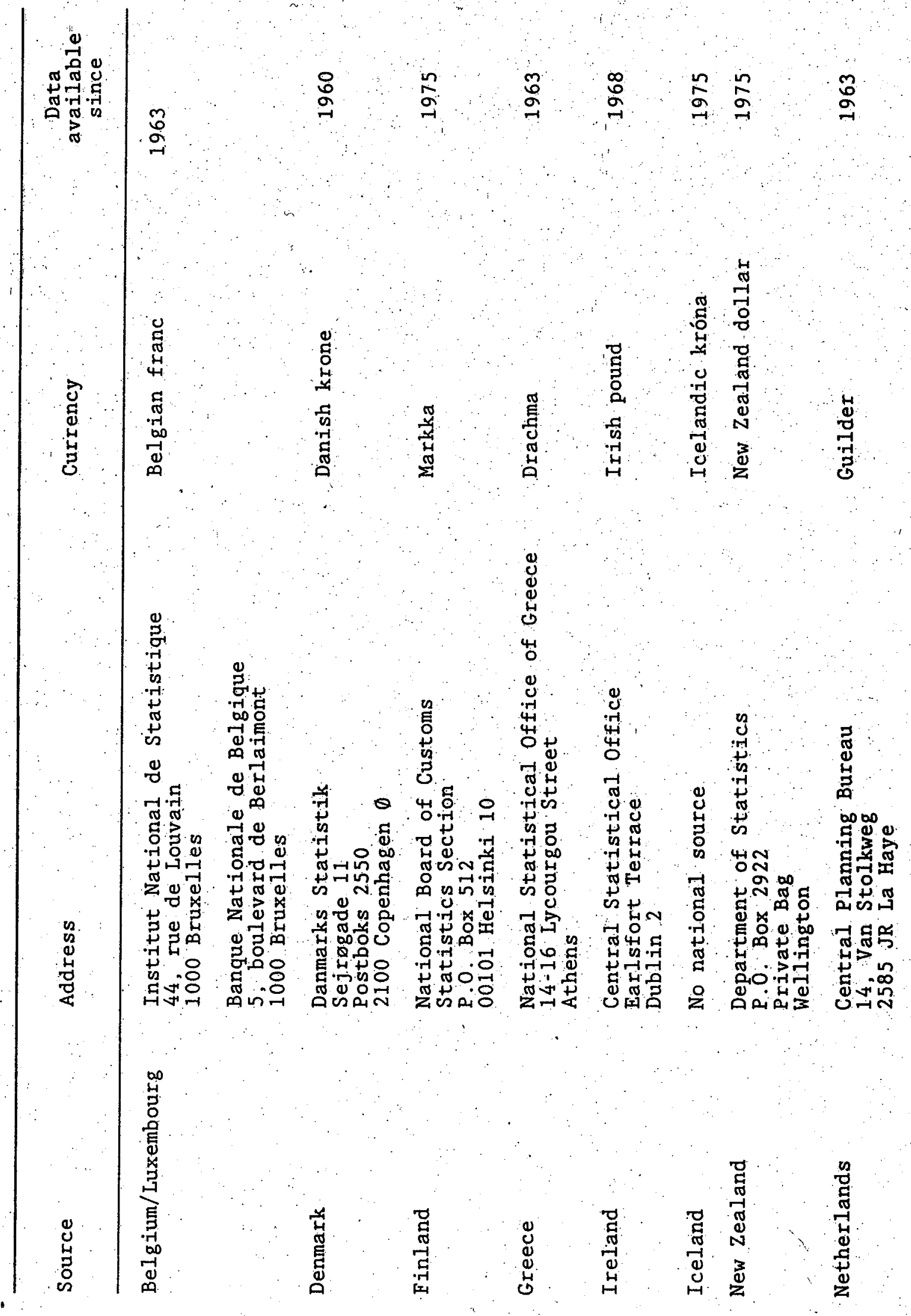




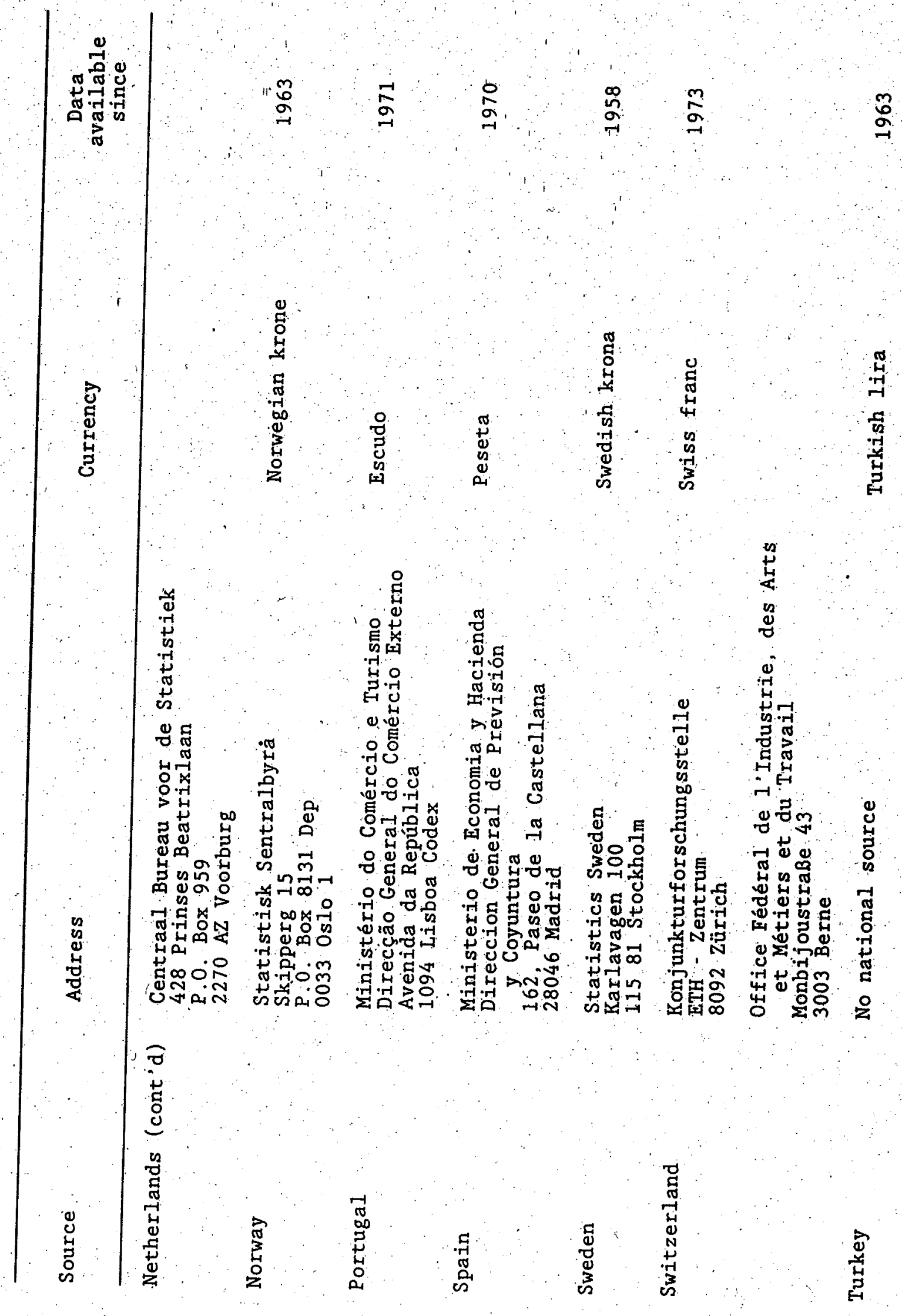




\section{Annex 4}

\section{IIST OF MNEMONICS}

Foreign trade indicators described in the main text are regularly used in the OECD'S INTERLINK model. The list of mnemonics related to these indicators and used in the ITIC diskette mentioned in page 51 is given below:

A. Foreign trade variables

$\begin{array}{ll}\text { XGVC } & \text { Total goods exports, volume } \\ \text { XFV } & \text { Food and agricultural products exports, volume } \\ \text { XEV } & \text { Energy exports, volume } \\ \text { XRV } & \text { Raw materials exports, volume } \\ \text { XMV } & \text { Manufactured goods exports, volume } \\ \text { XGC } & \text { Total goods exports, value } \\ \text { XF } & \text { Food and agricultural products exports, value } \\ \text { XE } & \text { Energy exports, value } \\ \text { XR } & \text { Raw materials exports, value } \\ \text { XM } & \text { Manufactured goods, exports, value } \\ \text { PXG } & \text { Total goods export price } \\ \text { PXF } & \text { Food and agricultural products export price } \\ \text { PXE } & \text { Energy export price } \\ \text { PXR } & \text { Raw materials export price } \\ \text { PXM. } & \text { Manufactured goods export price } \\ \text { MGVC } & \text { Total goods imports, volume } \\ \text { MFV } & \text { Food and agricultural products imports, volume } \\ \text { MEV } & \text { Energy imports, volume } \\ \text { MRV } & \text { Raw materials exports, volume } \\ \text { MMV } & \text { Manufactured goods, volume } \\ \text { MGC } & \text { Total goods imports, value } \\ \text { ME } & \text { Food and agricultural products imports, value } \\ \text { ME } & \text { Energy imports, value } \\ \text { MR } & \text { Raw materials imports, value } \\ \text { MM } & \text { Manufactured goods imports, value } \\ \text { PMG } & \text { Total goods import price } \\ \text { PMF } & \text { Food and agricultural products import price } \\ \text { PME } & \text { Energy import price } \\ \text { PMR } & \text { Raw materials import price } \\ \text { PMM } & \text { Manufactured goods import price } \\ & \end{array}$


B. Export market growth and export performance indicators

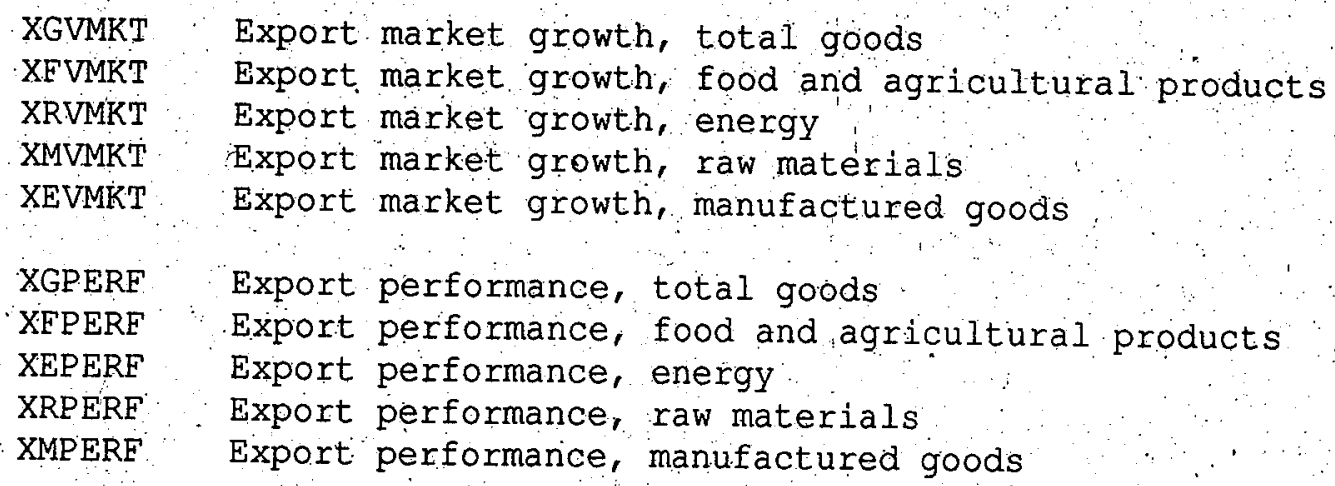

C. International competitivity indicators

ULCMB Index of unit labour costs in the manufacturing sector, in local currency

ULCMDR "Index of relative unit labour costs in the manufacturing sector, in a common currency (overall competitiveness)

PXMDR Index of relative export prices of manufactured goods, in a common currency (overall competitiveness)

ULCMDRA Index of relative unit labour costs in the manufacturing sector, in a common currency (export competitiveness)

PXMDRA Index of relative export prices of manufactured goods, in a common currency (export competitivéness) 


\section{ECONOMICS DEPARTMENT}

\section{WORKING PAPERS}

A complete list of Working Papers is available on request.

119. Ies indicateurs de compétitivité et de commerce internationaux de l'OCDE M. Durand, J. Simon and C. Webb (July 1992)

118. The Cost of reducing $\mathrm{CO}_{2}$ Emissions: A comparison of Carbon Tax Curves with GREEN (July 1992)

J. Oliveira-Martins, J.M. Burniaux, J. Martin and G. Nicoletti

117. The Cost of Reducing $\mathrm{CO}_{2}$ Emissions: A comparison of Carbon Tax Curves with GREEN (June 1992)

J. Oliveira-Martins, J.M. Burniaux, J. Martin and G. Nicoletti

116. GREEN: A Multi-sector Multi-region Dynamic General Equilibrium Model for Quantifying the Costs of Curbin $\mathrm{CO}_{2}$ Emissions: A technical Manual (May 1992)

115. The Costs of Reducing $\mathrm{CO}_{2}$ Emissions: Evidence from Green J-M Burniaux, J. P. Martin, G. Nicoletti and J. Oliveira Martins

114. Carbon Taxes and CO2 Emissions Targets: Results for Reducing Carbon Emissions

E. Lakis Vouyoukas, IEA

113. Use of the Edmonds-Reilly Model to Model Energy-Related Greenhouse Gas Emissions

D.W. Barns, J.A. Edmonds and J.M. Reilly, Pacific Northwest Laboratory, Washington, D.C:

112. The Welfare Effects of Fossil Carbon Restrictions: Results from a Recursively Dynamic Trade Model.

T. Rutherford, University of Western Ontario

111. Global 2100: Alternative Scenario for Reducing Carbon Emissions

Alan S. Manne, Stanford University

110. Energy Taxation and. Price Distortions in Fossil Fuel Markets: Some Implications for Climate Change: Police

P. Hoeller and J. Coppel

109. The Information Content of Interest Rate Spreads Across Financial Systems Frank. Browne and Warren Tease

108. Is there a future for capital income taxation? (March 1992) Jack M. Mintz 
107. A "Credit Crunch"? The Recent slowdown in Bank Lending and its Implications for Monetary Policy (March 1992) in Ban it Paul Francis $O^{\prime}$ Brien and Frank Browne

106. Energy Prices, Taxes and Carbon Dioxide Emissions, Pèter Hoeller and Markku Wallin

105. Savings Trends and Measurement Issue's Jeffrey Shafer, Jorgen Elmeskov, and Warren Tease

104. GREEN - A Multi-Region Dynamic General Equilibrium Model for Quantifying the Costs of Curbing Co2 Emissions: A Technical Manual (June 1991) J.M. Burniaux, J.P. Martin, G. Nicoletti, J. Oliveira-Martins

103. The Costs of Policies to Reduce Global Emissions of $\mathrm{CO}_{2}$ : Initial Simulation Results with GREEN (June 1991)

J.M. Burniaux, J.P. Martin, G. Nicoletti, J. Oliveira-Martins 102. Patterns of Recoveries for the Major Seven OECD Countries (June 1991)
Marco Mira d'Ercole.

101. P-Star as an Indicator of Inflationary pressure (March 1991) Peter Hoeller and Pierre poret

100. Old Age Income Maintenance (April 1991) Murray Petrie, Peter Sturm

99. The Measurement of Output and Factors of Production for the Business Sector in the 24 OECD Member Countries (March 1991)

Mark Keese; Gerard Salou, Pete Richardson 98. Macroeconomic Consequences of Financial Liberalisation: A Summary Report
(February 1991)

Adrian Blundell-Wignall and Frank Browne

97. Deregulation, Credit Rationing, Financial Fragility and Economic
Performance (February 1991) Michael Driscoll 96. Increasing Financial Market Integration, Real Exchange Rates and

Adrian Blundell-Wignall and Frank Browne

95. Financial Liberalisation, Asset Prices and Exchange Rates (February 1991)
Marcus Miller and Paul Weller

94. Financial Liberalisation and International Trends in Stock, Corporate Paul Kupiec 


\section{The OECD International Trade and Competitiveness Indicators on PC diskette}

The International trade indicators described in this working Paper will shortiy be available as part of a new OECD PC diskette data product.

The OECD "International Trade and Competitiveness Indicators" (ITCI) statistical series are designed for use in a wide range of empirical analyses related to the international trade performance of OECD Member countries. The set of diskettes will include principal series for external trade classified by the broad SITC commodity groups described'in this paper, in nominal and constant price value terms, along with corresponding price deflators, market shares and competitiveness indicators, these statistics will be available in a consistent quarterly form for 24 OECD Member countries the length of individual series is determined by the availability of individual country source information, but in general all series will be available from 1975 onwards.

The ITCI data set will be supplied on alternative 5 1/4" or 3 I/2" IBM PC-compatible diskettes. They will be updated to take account of new information and data revisions on a twice-yearly basis (annual subscription rates and contractual terms for multiple and time share data subscriptions are also available on request).

If you are interested in this new service or require more specific information about its content and availability, you are invited to complete the following questionnaire and return it to:

ITCI Project

Quantitative Analysis and Support Division

Economics Department.

OCDE, 2 rue André-Pascàl

75775 Paris Cedex 16

France

Name and address:

Title/Function:

Organisation:

Principle activity: Commercial/Educational/Government/Research/other $\left(^{*}\right)$

Type of application: Statisticai/Econometric/Economic analysis/Other $(*)$

PC type: IBM-compatible/other $\left(^{*}\right)$

Applications software:

* Please specify as appropriate 